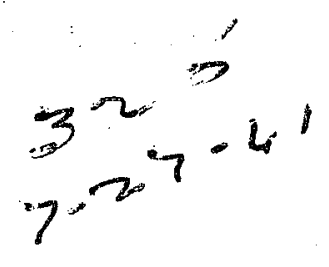

$$
\begin{gathered}
\text { ORNL-3068 } \\
\text { UC-10 - Chemical Separations Processes }
\end{gathered}
$$
for Plutonium and Uranium

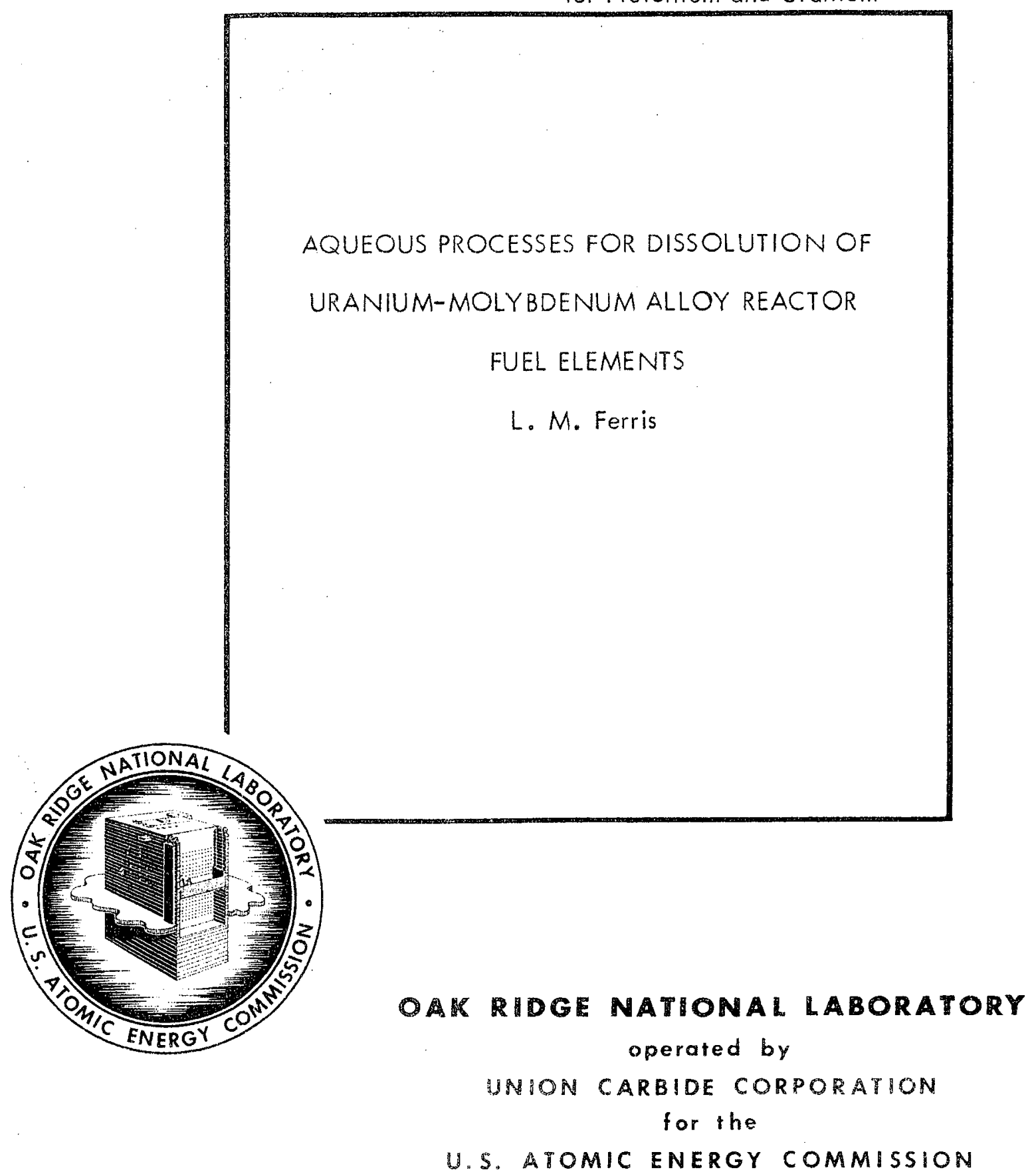




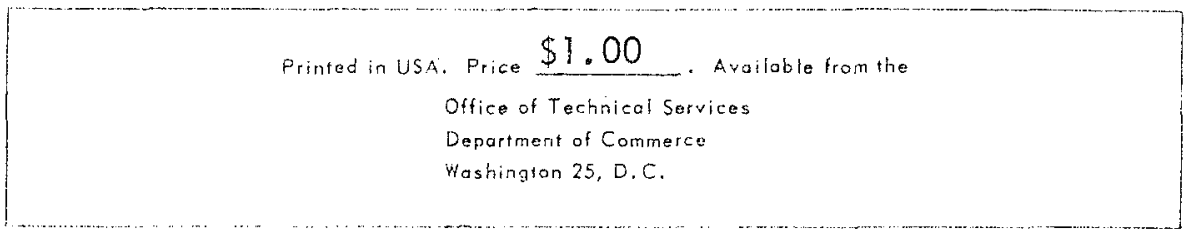

LEGAL NOTICE

This report was prepared as un necount of Government sponsored work. Neither the United States, nor the Commission, nor any person acting on behalf of the Commission:

A. Makes ony warronty or representation, expressed or implied, with respect to the accurocy, completeness, or usefulness of the information contained in this repart, or that the use of any information, apparatus, method, or process disclosed in this report moy not infringe privately owned rights; or

B. Assumes any labilities with respect to the use of or for damages resulting from the use of any information, apparafus, method, or process disclosed in this report.

As used in the obove. "person acting on betulf of the Commission" includes any emplayee or contracior of the Commission, or employeo of such confractor, to the extent that such employee of controctor of the Comenission, or enplayec of such contector prepores, disseminates, or provides access to, uny intormation pursuanit to his employment or contract with the Commission, or his employment with such controctor. 


\author{
Contract No. W-7405-eng-26 \\ CHEMICAL TECHNOLOGY DIVISION \\ Chemical Development Section B
}

\title{
AQUEOUS PROCESSES FOR DISSOLUTION OF URANIUM- MOLYBDENUM ALLOY REACTOR FUEL ELEMENTS
}

L. M. Ferris

Technician

J. F. Land

DATE ISSUED

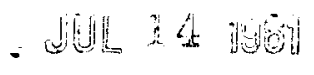

Oak Ridge National Laboratory Oak Ridge, Tennessee Operated by Union Carbide Corporation for the

U. S. Atomic Energy Commission 


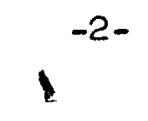

\section{ABSTRACT}

Methods for dissolving unirradiated uranium-molybdenum alloy reactor fuels in nitric acid, nitric acid-ferric nitrate, and nitric acid-phosphoric acid solutions were studied on a laboratory scale. Flowsheets based on the results propose dissolution of alloys containing $3 \%$ molybdenum in boiling $6 \mathrm{M} \mathrm{HNO}_{3}$ to yield stable solutions that are $0.6 \mathrm{M}$ in uranium and 3 to $4 M$ in nitric acid. The uranium can then be easily decontaminated and recovered in a conventional Purex-type tributyl phosphate solvent extraction process. Alloys containing $10 \%$ molybdenum would be dissolved in boiling $11 \mathrm{M}_{3} \mathrm{HNO}_{3}$, allowing molybdic oxide to precipitate. The molybdic oxide, which carries 5-10\% of the uranium, is removed by centrifugation and the acidity of the supernatant solution adjusted to allow recovery of the uranium by Purex-type solvent extraction procedures. The uranium carried by the molybdic oxide is recovered after the $\mathrm{MoO}_{3}$ is dissolved in warm $5 \mathrm{M} \mathrm{NaOH}$. Less than $0.1 \%$ of the uranium is solubilized during the caustic dissolution.

Alternative methods investigated involve dissolution in nitric acid containing 0.5 to 1 M ferric nitrate to complex the molybdenum. These techniques lead to undesirably large volumes of high-level solvent extraction waste solutions. Phosphate ion is also effective in complexing molybdenum; however, its use in the dissolvent would be purposeless since it must be complexed with iron during solvent extraction.

Rates of reaction of the various alloys and the solubility of molybdic oxide were determined in nitric acid, nitric acid-ferric nitrate, and nitric acid-phosphoric acid solutions. 


\section{Page}

2.0 Flowsheets

2.1 Alloys Containing 3\% Molybdenum

2.2 Alloys Containing 10\% Molybdenum

3.0 Experimental 10

3.1 Decladding 10

3.2 Core Dissolution 11

3.3 Solubility Data 23

3.4 Corrosion Studies 32

4.0 Miscellaneous Related Studies 34

4.1 Dissolution in Dilute Aqua Regia 34

4.2 Other Potential Complexing Agents for Molybdenum 34

4.3 Reduction of Solvent Extraction Waste Volumes 34

4.4 Decladding of Zirconium-clad Fuels 35

5.0 References 35 


\subsection{INTRODUCTION}

The objective of the laboratory studies reported here was the development of methods for dissolving uranium-molybdenum alloy reactor fuel elements in aqueous nitrate solutions from which the uranium and plutonium could be decontaminated and recovered by Purex-type (I) solvent extraction processes. The methods evolved are applicable to the processing of the Consumers Public Power (U-10\% MO) and the Detroit Edison blanket (U-3\% Mo) fuel elements. Both these elements are clad in stainless steel and bonded with sodium $(\underline{2}, \underline{3})$. Because of the hazard involved in reacting sodium with mineral acids, it was assumed that the cladding and bond would be removed mechanically and that the core alloy would probably be recanned in aluminum before aqueous processing (4a). Laboratory studies consisted of an extensive investigation of dissolution of unirradiated alloys in nitric acid, nitric acid-ferric nitrate, and nitric acid-phosphoric acid solutions since chemical removal of the aluminum can presents no problems.

Preliminary work on the dissolution of uranium-molybdenum alloys in nitric acid, done at ORNL in 1955, has been reported (). In a process used in the USSR for U-Mo-Mg alloy fuels (6), either ferric nitrate or phosphoric acid was used to complex molybdenum in $5 \underline{\mathrm{M}} \mathrm{HNO}_{3}$ solutions. At Hanford Atomic Products Operation (HAPO) considerable effort has been expended in the development of processes involving dissolution in nitric acid (7) or nitric acid-ferric nitrate (8) solutions. While the recent work at ORNL paralleled that at HAPO somewhat, the objective was different. At HAPO, Redox-type solvent extraction was desired, while Purex was the preferred solvent extraction method at ORNL. As a consequence, dissolution studies at ORNL were aimed at the preparation of solutions containing $2-4 \mathrm{M}_{3} \mathrm{HNO}_{3}$ instead of the slightly acidic or acid-deficient aluminum nitrate solutions required for the Redox process. Preliminary results of recent ORNL studies were reported previously (4b). Savannah River Laboratory has proposed total dissolution of Detroit Edison fuel (zirconium-clad U-lo\% Mo alloy). The total dissolution process proposed involves dissolution of the zirconium in dilute hydrofluoric acid followed by addition of $3 \underline{\mathrm{M}} \mathrm{HNO}_{3}$ to dissolve the alloy (9). A dilute solution is maintained so that molybdenum does not 
precipitate during dissolution.

In addition to the development of aqueous methods for uranium-molybdenum alloy fuels, a nonaqueous method involving reaction of the alloys with air containing a chlorinating agent has been developed (10). By this method, molybdenum is separated from the uranium as a volatile oxychloride at $300-500^{\circ} \mathrm{C}$. The ash is $\mathrm{U}_{3} \mathrm{O}_{8}$ containing only 5-10\% of the original molybdenum and can be dissolved easily in dilute nitric acid to produce solutions suitable as feeds for Purex-type solvent extraction processes.

The preliminary solvent extraction experiments showing the feasibility of using a Purex-type process with solutions containing molybdenum were kindly performed by J. R. Flanary and J. H. Goode, ORNL Chemical Technology Division. Chemical analyses were made by the groups of G. R. Wilson and W. R. Laing of the ORNL Analytical Chemistry Division. The author is particularly indebted to $R$. I. Sherman for his aid in obtaining $x$-ray data for the various solid molybdenum compounds encountered in the course of the work. Special credit is also due H. Kubota for developing a technique for determining the acidity of nitric acid-phosphoric acid solutions containing uranium and molybdenum.

\subsection{FLOWSHEETS}

Conditions selected as optimum, primarily from solvent extraction waste volume considerations, result from dissolution of $3 \%$ molybdenum alloys in $6 \mathrm{M} \mathrm{HNO}_{3}$ and the dissolution of $10 \%$ molybdenum alloys in $11 \mathrm{M} \mathrm{HNO}_{3}$. A stable solution was obtained from the 3\% alloys, but most of the molybdenum from a 10\% alloy was precipitated. Alternative processes based on the complexing of molybdenum with ferric ion are also presented.

\subsection{Alloys Containing 3\% Molybdenum}

The process for elements containing uranium-3\% molybdenum alloy (e.g., the Detroit Edison Blanket) involves dissolution of the aluminum can (which may be present as a result of the prior recanning step) in boiling $\mathrm{NaOH}-\mathrm{NaNO}_{3}$ solution (11) followed by dissolution of the alloy in boiling 
$6 \mathrm{M} \mathrm{HNO}_{3}$ (Fig. Ia). Less than $0.1 \%$ of the uranium is lost to the decladding solution. Dissolution of the 0.415-in. -dia alloy requires about $6 \mathrm{hr}$. The product of the core dissolution contains $0.6 \underline{\mathrm{M}}$ uranium, about $0.04 \underline{\mathrm{M}}$ molybdenum, and about $3.4 \mathrm{M}$ hydrogen ion. No precipitation occurs at any time during core dissolution. Uranium and plutonium are decontaminated and recovered by Purex-type solvent extraction methods. Preliminary studies (4b) showed that the traces (about $0.013 \mathrm{M}$ ) of molybdenum in the feed had no adverse effect on the extraction of uranium with $30 \%$ TBP.

Large volumes of solvent extraction waste would result from this process unless the waste solutions were given special treatment. Two alternatives seem feasible: (1) neutralization followed by evaporation, and (2) a boildown to precipitate the molybdenum and recover acid (sect. 4.3). The molybdic oxide precipitated during boildown would be dissolved in sodium hydroxide solution for storage.

In the alternative process for uranium-3\% molybdenum fuels, dissolution is achieved in boiling $8 \mathrm{MHNO}_{3}-0.5 \mathrm{M} \mathrm{Fe}\left(\mathrm{NO}_{3}\right)_{3}$. Iron was selected as the complexing agent instead of phosphate because it was necessary to complex phosphate with iron prior to solvent extraction. By complexing molybdenum with $0.5 \mathrm{M}$ ferric ion, a solvent extraction feed containing $1 \mathrm{M}$ uranium and about $3 \mathrm{M}$ hydrogen ion can be produced (Fig. Ib). Preliminary solvent extraction studies on solutions spiked with plutonium showed that molybdenum had no adverse effect on the extraction with 30\% TBP in 7 stages and that the stage requirements were no greater than those for normal Purex operation $(4 \mathrm{~b})$.

The chief disadvantage in using iron is that the waste volumes from solvent extraction are very large. Even if the molybdenum could be concentrated to $25 \mathrm{~g} /$ liter, about $1100 \mathrm{gal}$ of high-activity waste would be generated for each ton of uranium processed.

\subsection{Alloys Containing 10\% Molybdenum}

Fuels containing 10\% molybdenum (e.g., the CPPD-I) are dissolved in boiling $11 \mathrm{M} \mathrm{HNO}_{3}$ () after the aluminum can is removed by the standard caustic decladding method (II) (Fig. 2). Soluble uranium losses to the 
Detroit Edison Blanket (0.415-in. -dia rods)

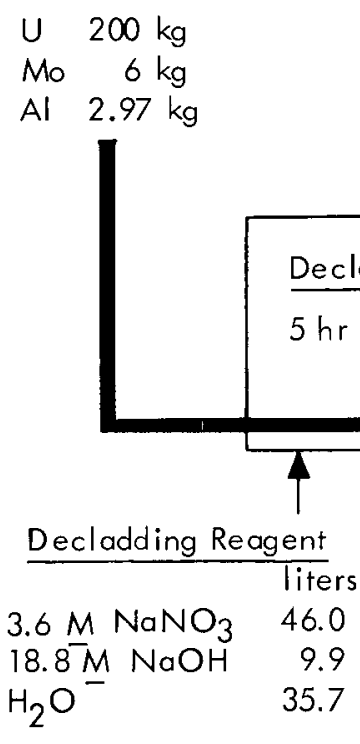

$6 \mathrm{M} \mathrm{HNO}_{3} 8 \mathrm{MHNO}$

$$
\begin{array}{cc}
6 \underline{\mathrm{M}} \mathrm{HNO}_{3} & 8 \mathrm{M} \mathrm{HNO}_{3}- \\
1400 \text { liters } & 0 . \overline{\mathrm{M} \mathrm{Fe}}\left(\mathrm{NO}_{3}\right)_{3} \\
& 8 \overline{40} \text { liters }
\end{array}
$$

(a)

(b)

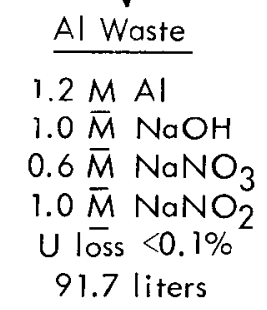

\section{Core Dissolution}

$6 \mathrm{hr}$ (a) $104^{\circ} \mathrm{C}$

(b) $112^{\circ} \mathrm{C}$

Fig. 1. Processes for dissolution of uranium--3\% molybdenum alloy fuels in (a) nitric acid solution and (b) nitric acid--ferric nitrate solution. No molybdenum precipitates during dissolution in either case. 
CPPD - 1 Fue

$(0.59$-in. -dia rods)

$\mathrm{U} \quad 200 \mathrm{~kg}$

Mo $22 \mathrm{~kg}$

AI $2.97 \mathrm{~kg}$

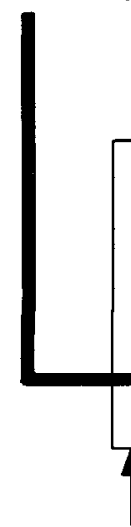

Decladding Reagent

$3.6 \mathrm{M} \mathrm{NaNO}_{3} 46.0$ liters

$18.8 \mathrm{M} \mathrm{NaOH} 9.9$ liters

$\mathrm{H}_{2} \mathrm{O}$

35.7 liters

\section{CORE DISSOLVENT}

$11 \mathrm{M} \mathrm{HNO}_{3}$

$76 \overline{9}$ liters

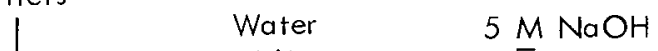

564 liters $\quad 2 \overline{7} 5$ liters

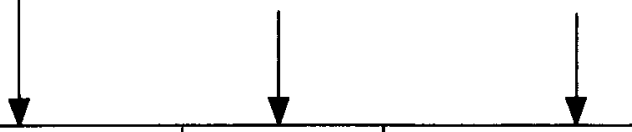

\begin{tabular}{|c|c|c|}
\hline $\begin{array}{c}\text { Step } 2 \\
\text { Core Dissolution }\end{array}$ & $\begin{array}{l}\text { Step } 3 \\
\text { Washing } \\
\end{array}$ & $\begin{array}{c}\text { Step } 4 \\
\mathrm{MoO}_{3} \text { Dissolution }\end{array}$ \\
\hline $5 \mathrm{hr} \quad 113^{\circ} \mathrm{C}$ & & $\begin{array}{l}2 \mathrm{hr} \quad 70^{\circ} \mathrm{C} \\
\text { Solids vol } 154 \text { liters } \\
\text { Solids contain } 5-10 \% \\
\text { of the uranium }\end{array}$ \\
\hline
\end{tabular}

Al Waste

$1.2 \mathrm{M} \mathrm{Al}$

$1.0 \bar{M} \mathrm{NaOH}$

$0.6 \bar{M} \mathrm{NaNO}_{3}$

$1.0 \overline{\mathrm{M}} \mathrm{NaNO}_{2}$

$\cup \operatorname{loss}<0.1 \%$

91.7 liters

UNCLASSIFIED

ORNL-LR-DWG. 55536

Fig. 2. Process for dissolution of uranium-10\% molybdenum alloy fuels in concentrated nitric acid. Molybdenum precipitates during dissolution. Uranium sorbed by $\mathrm{MoO}_{3}$ is dissolved in nitric acid after the $\mathrm{MOO}_{3}$ is dissolved in caustic and removed. 
decladding solution are less than 0.1\%. The 0.59-in.-dia core is dissolved in $5 \mathrm{hr}$ in a volume of boiling acid sufficient to produce a solution containing $260 \mathrm{~g}$ of uranium per liter; the acid concentration after dissolution is about $6 \mathrm{M}$. The uranium concentration is then adjusted to about $0.6 \underline{\mathrm{M}}$ for solvent extraction.

Most of the molybdenum precipitates, as $\mathrm{MOO}_{3}$, during core dissolution. This solid, after centrifugation, occupies a volume which is $20-30 \%$ of the original solution volume. After about three washes, the centrifuged solids contain 5-10\% of the uranium (Table 1) and about $2 \%$ of the plutonium (7). Recovery of the sorbed uranium is greatly improved when more efficient washing and solid-liquid separation techniques are used. For example, the washed solids contained only about $0.1 \%$ of the uranium when the solids were separated by vacuum filtration before washing (Table 1). Residual uranium, and probably plutonium compounds, can be recovered by dissolution in nitric acid after the $\mathrm{MOO}_{3}$ is dissolved in $200 \%$ stoichiometric excess of hot $5 \mathrm{M} \mathrm{NaOH}$. No significant fraction of the uranium (and probably plutonium) is solubilized when the $\mathrm{MOO}_{3}$ is dissolved (Table 1).

The principal advantage of this process is the separation of most of the molybdenum from the uranium prior to solvent extraction. This separation should result in low-volume Purex-type solvent extraction wastes. The chief disadvantage is the necessity of recovering relatively large amounts of solid molybdic oxide containing significant amounts of uranium and plutonium by centrifugation or filtration. The process could also be used for elements containing $3 \%$ molybdenum; centrifugation problems with this alloy would undoubtedly be less severe than with the $10 \%$ alloy.

Alloys containing $10 \%$ molybdenum can be dissolved in nitric acid-ferric nitrate solutions without precipitation occurring. A solvent extraction feed solution containing $0.5 \mathrm{M}$ uranium, $0.14 \mathrm{M}$ molybdenum, and $3.0 \mathrm{M} \mathrm{HNO}_{3}$ is obtained by dissolution in boiling $5.5 \mathrm{M}^{\mathrm{HNO}} \mathrm{H}^{-1} \underline{\mathrm{M}} \mathrm{Fe}\left(\mathrm{NO}_{3}\right)_{3}$. 
Table 1. Dissolution of Uranium-10\% Molybdenum

$$
\text { Alloy in Bolling } 11 \mathrm{M} \mathrm{HNO}_{3}
$$

Solution composition prior to solid-liquid separation: about $6 \mathrm{M} \mathrm{HNO}_{3}$ containing $260 \mathrm{~g}$ of uranium per liter

\begin{tabular}{llllclc}
\hline $\begin{array}{c}\text { Mo in } \\
\text { Aloy } \\
\%\end{array}$ & $\begin{array}{c}\text { Dissolu- } \\
\text { tion } \\
\text { Time, } \\
\mathrm{hr}\end{array}$ & $\begin{array}{c}\text { Separation } \\
\text { Method }\end{array}$ & $\begin{array}{c}\text { Wash } \\
\text { Solution }\end{array}$ & $\begin{array}{c}\text { Mo in Filtrate } \\
\text { or Centrifugate, } \\
\%\end{array}$ & $\begin{array}{c}\text { U Content, } \% \\
\text { Washed NaOH } \\
\text { Solids Solution }\end{array}$ \\
\hline 8.4 & 5 & Filtration & 1 M HNO & 6.0 & 0.1 & 0.08 \\
8.4 & 3 & Centrifugation Water & 8.4 & 4.1 & 0.11 \\
8.4 & 6 & Filtration & Water & 5.6 & 0.1 & 0.22 \\
10 & 4 & Centrifugation Water & 20.7 & 7.2 & 0.005 \\
\hline
\end{tabular}

Wash solutions generally added in three portions.

$\mathrm{b}^{\mathrm{MoO}} 3$ solids dissolved in $200 \%$ excess of hot $5 \mathrm{M} \mathrm{NaOH}$.

\subsection{EXPERIMENTAL}

\subsection{Decladding}

Both the CPPD-I core and the Detroit Edison blanket fuels are bonded to stainless steel jackets with sodium. While there appears to be no danger of a vapor-phase explosion if the stainless steel and sodium were dissolved in sulfuric acid (12), sufficient uncertainty exists regarding the containment of the sodium-water reaction that mechanical removal of the clad and bond appears to be the safest approach. After mechanical dejacketing, the core alloys would probably be recanned in aluminum to facilitate subsequent handling (4a). Chemically, aluminum offers no special problems. Uranium losses were acceptably low when the aluminum was dissolved in sodium hydroxide-sodium nitrate solutions (Table 2). When sulfuric acid is used for dissolution of the original stainless steel cladding, no serious uranium loss results. 
Table 2. Losses from Various Uranium-Molybdenum

Alloys to Typical Decladding Solutions

\begin{tabular}{|c|c|c|c|}
\hline \multirow[b]{2}{*}{$\begin{array}{c}\text { Boiling Decladding } \\
\text { Solution }\end{array}$} & \multicolumn{3}{|c|}{ Uranium Losses in $24 \mathrm{hr}$, \% } \\
\hline & $\begin{array}{c}\text { From 3\% Mo } \\
\text { Alloys }\end{array}$ & $\begin{array}{c}\text { From } 8.4 \% \text { Mo } \\
\text { Alloys }\end{array}$ & $\begin{array}{l}\text { From 10\% Mo } \\
\text { Alloys }\end{array}$ \\
\hline $2 \mathrm{M} \mathrm{NaOH}-1.78 \mathrm{M} \mathrm{NaNO}_{3}$ & 0.00002 & 0.00002 & 0.00005 \\
\hline $4 \mathrm{MH}_{2} \mathrm{SO}_{4}$ & 0.57 & $\begin{array}{l}0.022 \\
0.028\end{array}$ & - \\
\hline $6 \mathrm{M} \mathrm{H}_{2} \mathrm{SO}_{4}$ & $\begin{array}{l}0.34 \\
1.6\end{array}$ & $\begin{array}{l}0.055 \\
0.045\end{array}$ & $-\overline{1}-$ \\
\hline $\begin{array}{c}3.8 \mathrm{M}_{\text {stainless }}^{\mathrm{H}_{2} \mathrm{SO}_{4}}-1.8 \mathrm{M} \\
\text { steel }\end{array}$ & 0.31 & $0.0027^{\mathrm{a}}$ & -- \\
\hline
\end{tabular}

axposure time $5 \mathrm{hr}$ in this experiment.

\subsection{Core Dissolution}

Dissolution in Nitric Acid. Uranium-molybdenum alloys containing up to 10\% molybdenum dissolved rapidly in nitric acid. Because of its low solubility, molybdic oxide usually precipitated during the dissolution. The dissolution rate increased with increasing acid concentration and with the fuel molybdenum content. The three alloys studied dissolved more rapidy than uranium metal, maximum rates at each acid concentration being for the $10 \%$ molybderum alloy (Fig. 3). For each alloy the rate data obeyed approximately the equation

$$
\text { Rate }\left(\mathrm{mg} \min ^{-1} \mathrm{~cm}^{-2}\right)=\mathrm{k}\left(\mathrm{HNO}_{3}, \underline{\mathrm{M}}\right)^{\mathrm{n}}
$$

The log-log plots in Fig. 3 show that generally the data could be represented by the above equation when the rate was less than about $100 \mathrm{mg} \mathrm{min}{ }^{-1} \mathrm{~cm}^{-2}$. The slopes of these lines, $n$, indicated a second- or third-power dependence of the rate on the nitric acid concentration (Table 3). Irrespective of the molybdenum content of the alloy, the rate was always greater than $10 \mathrm{mg} \mathrm{min} \mathrm{m}^{-1} \mathrm{~cm}^{-2}$ in solutions in which the acid concentration was greater than 5 M. Recent studies have shown that the dissolution rate may be higher after irradiation (13). Rates expressed in $\mathrm{mg}$ per minute per square centimeter may be converted to rates in mils per hour by use of the equation

$$
\text { Rate }(\mathrm{mils} / \mathrm{hr})=1.3 \text { Rate }\left(\mathrm{mg} \mathrm{min}{ }^{-1} \mathrm{~cm}^{-2}\right. \text { ) }
$$




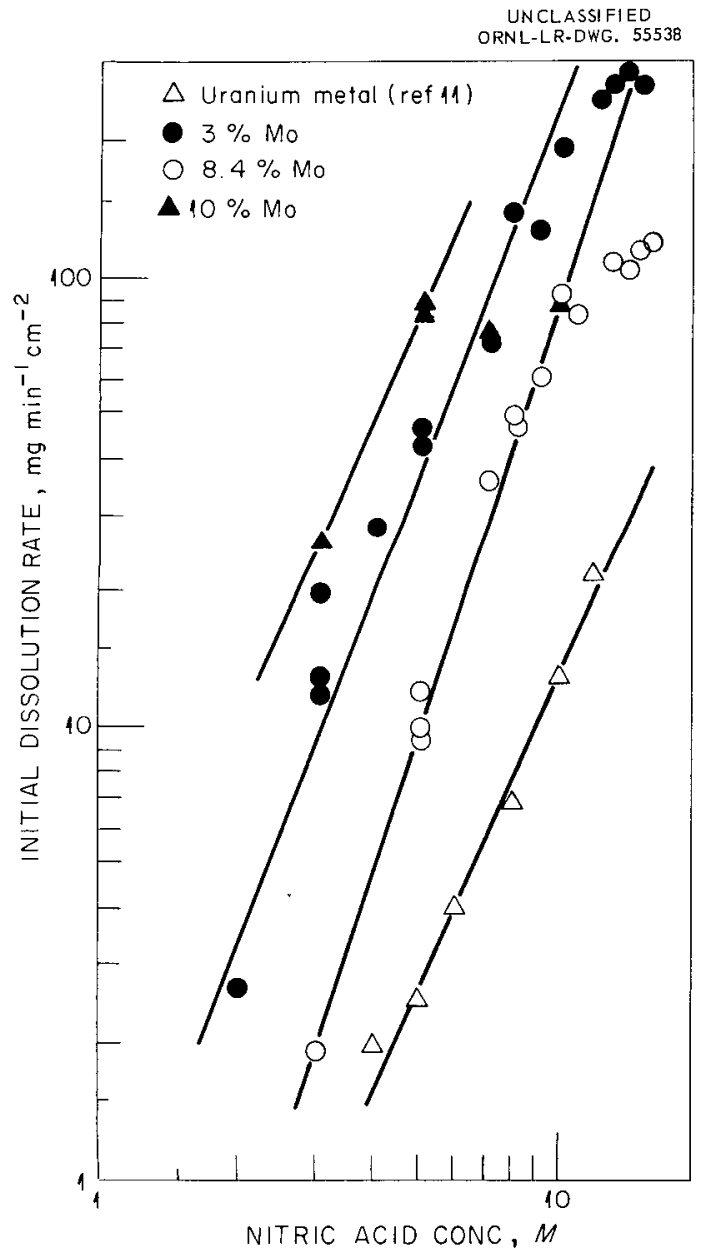

Fig. 3. Initial rates of dissolution of uranium-molybdenum alloys in boiling nitric acid.

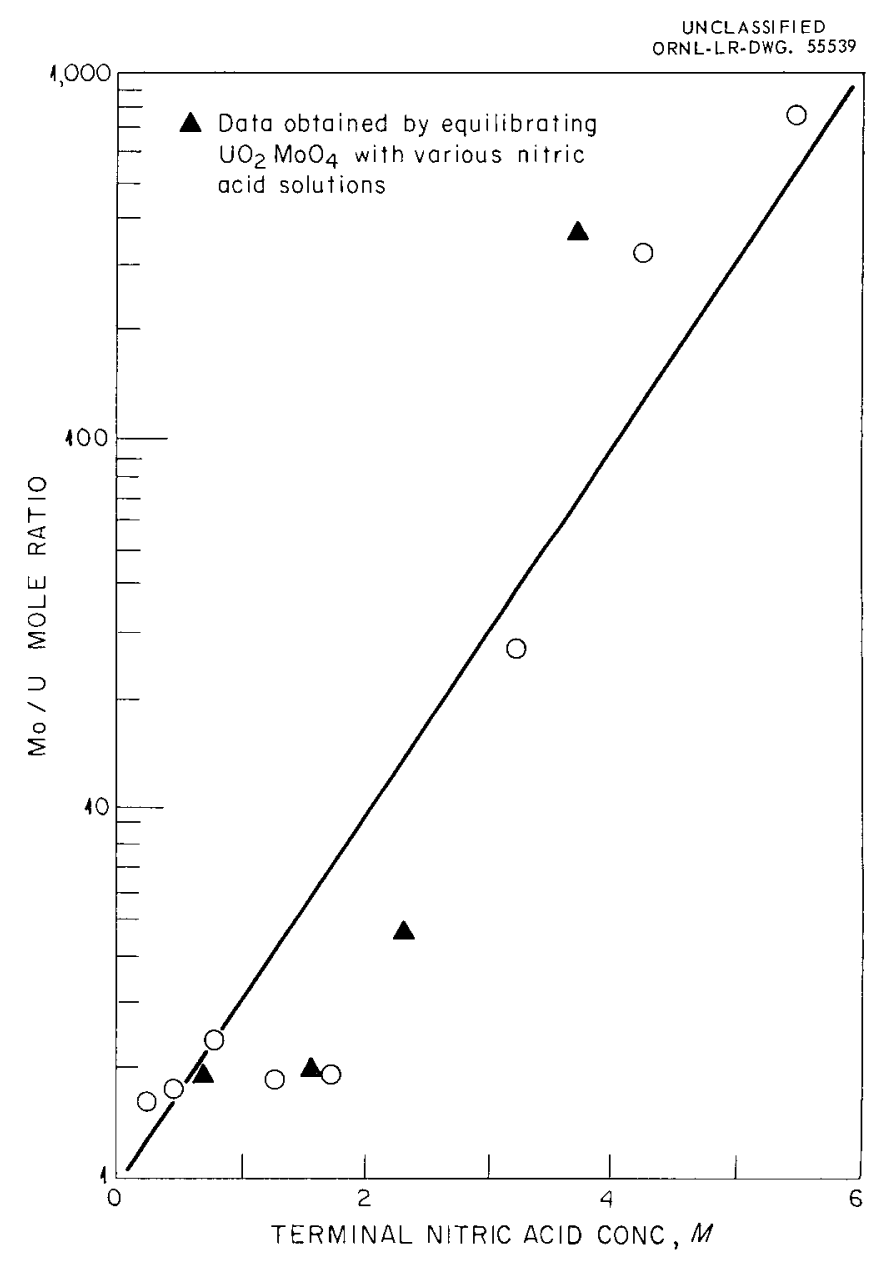

Fig. 4. Molybdenum/uranium mole ratio in solids produced during dissolution of uraniummolybdenum alloys in boiling nitric acid. Final uranium concentration was $1-1.5 \mathrm{M}$ in each case. 
Table 3. Dissolution of Uranium-Molybdenum Alloys in Nitric Acid: Constants Obtained When Data Were Expressed by the Equation

$$
\text { Rate }\left(\mathrm{mg} \mathrm{min}-\mathrm{cm}^{-2}\right)=\mathrm{k}\left(\mathrm{HNO}_{3}, \mathrm{M}\right)^{\mathrm{n}}
$$

\begin{tabular}{ccc}
\hline $\begin{array}{c}\text { Mo Content of } \\
\text { Alloy, \% }\end{array}$ & Slope $(\mathrm{n})$ & Intercept $(\mathrm{k})$ \\
\hline $0^{\mathrm{a}}$ & 2.23 & 0.0795 \\
3 & 2.46 & 0.763 \\
8.4 & 3.25 & 0.0517 \\
10 & 2.33 & 2.02 \\
\hline
\end{tabular}

$a_{\text {Data for uranium metal taken from reference } 11 .}$

Acid Consumption. Dissolution in boiling 3 to 11 M $\mathrm{HNO}_{3}$ of alloys containing up to $10 \%$ molybdenum resulted in the apparent consumption of 4-7 moles of hydrogen ion for each mole of alloy dissolved. Since the extent to which the nitrogen oxides are refluxed is dependent on the type of condenser used, these data indicate only the approximate stoichiometry of the reaction. Two- to 20-g samples of the alloys were dissolved in 500-ml flasks fitted with two 21 -in.-long condensers. With the alloy containing $8.4 \%$ molybdenum, between 3.4 and 4.6 moles of hydrogen ion was consumed for each mole of alloy dissolved regardless of the acid concentration (Table 4). The uranium concentration in the final solution varied from 0.4 to $2 \mathrm{M}$. With both the 3 and 10\% alloys the amount of hydrogen ion consumed appeared to increase as the acid concentration increased. For first-approximation calculations it is convenient to assume that 4 moles of nitric acid is required to dissolve 1 mole of alloy.

Formation of Uranyl Molybdates. When the terminal acid concentration was less than about $4 \underline{M}$, the precipitate contained significant amounts of uranium (Table 5). The molybdenum-uranium mole ratio in the solid varied from about 1 (which would correspond to the normal molybdate, $\mathrm{UO}_{2} \mathrm{MoO}_{4}$ ) to about 1000 as 
Table 4. Consumption of Acid in Dissolution of Uranium-Molybdenum Alloys in Boiling $3-11 \mathrm{M} \mathrm{HNO}_{3}$

\begin{tabular}{|c|c|c|c|c|}
\hline $\begin{array}{l}\text { Mo in } \\
\text { Alloy, \% }\end{array}$ & $\begin{array}{c}\text { Initial } \\
\mathrm{HNO}_{3} \\
\mathrm{Con}^{3} \\
\mathrm{M} \\
\end{array}$ & $\begin{array}{c}\text { Alloy } \\
\text { Dissolved, } \\
\text { moles }\end{array}$ & $\begin{array}{c}\mathrm{H}^{+} \\
\begin{array}{c}\text { Consumed, } \\
\text { moles }\end{array} \\
\end{array}$ & $\frac{\text { Moles } \mathrm{H}^{+} \text {Consumed }}{\text { Mole Alloy Dissolved }}$ \\
\hline $\begin{array}{l}3 \\
3 \\
3 \\
3 \\
3 \\
3 \\
3\end{array}$ & $\begin{array}{r}3.0 \\
5.0 \\
6.0 \\
8.0 \\
8.0 \\
11.0 \\
11.0\end{array}$ & $\begin{array}{l}0.0598 \\
0.0339 \\
0.0883 \\
0.0410 \\
0.0848 \\
0.0832 \\
0.0470\end{array}$ & $\begin{array}{l}0.250 \\
0.122 \\
0.380 \\
0.177 \\
0.398 \\
0.580 \\
0.191\end{array}$ & $\begin{array}{l}4.2 \\
3.6 \\
4.3 \\
4.3 \\
4.7 \\
7.0 \\
4.1\end{array}$ \\
\hline $\begin{array}{l}8.4 \\
8.4 \\
8.4 \\
8.4\end{array}$ & $\begin{array}{r}3.0 \\
8.0 \\
11.0 \\
11.0\end{array}$ & $\begin{array}{l}0.0242 \\
0.0366 \\
0.0615 \\
0.0330\end{array}$ & $\begin{array}{l}0.081 \\
0.130 \\
0.280 \\
0.127\end{array}$ & $\begin{array}{l}3.4 \\
3.6 \\
4.6 \\
3.9\end{array}$ \\
\hline $\begin{array}{l}10 \\
10 \\
10 \\
10 \\
10 \\
10 \\
10 \\
10 \\
10\end{array}$ & $\begin{array}{r}4.0 \\
5.0 \\
5.0 \\
6.0 \\
8.0 \\
8.0 \\
10.0 \\
11.0 \\
11.0\end{array}$ & $\begin{array}{l}0.0539 \\
0.0686 \\
0.0095 \\
0.0645 \\
0.0706 \\
0.0080 \\
0.0674 \\
0.0727 \\
0.0442\end{array}$ & $\begin{array}{l}0.192 \\
0.239 \\
0.028 \\
0.238 \\
0.289 \\
0.031 \\
0.340 \\
0.386 \\
0.227\end{array}$ & $\begin{array}{l}3.6 \\
3.5 \\
2.9 \\
3.7 \\
4.1 \\
3.9 \\
5.0 \\
5.3 \\
5.1\end{array}$ \\
\hline
\end{tabular}

the terminal acid concentration increased from 0 to about 6 M (Fig. 4 and Table 5). Apparently, a series of uranyl molybdates, which are similar to the sodium molybdates (14), is formed in solutions of low acidity. X-ray analyses indicated that the solid was $\mathrm{MOO}_{3}$ when the terminal acidity was greater than $4 \mathrm{M}$; therefore uranium carried by the solid during dissolution in concentrated acid is probably only sorbed and can be recovered by washing with water or acid. Water is preferred for the washing to minimize solubilization of the molybdenum (see data on the solubilities of $\mathrm{MoO}_{3}$ and $\mathrm{UO}_{2} \mathrm{MOO}_{4}$ in nitric acid, sect. 3.3). 
Table 5. Solids Produced During Dissolution of Uranium-Molybdenum Alloys in Nitric Acid

\begin{tabular}{|c|c|c|c|c|c|c|}
\hline \multirow{2}{*}{$\begin{array}{c}\text { Mo in } \\
\text { Alloy, } \\
\%\end{array}$} & \multirow{2}{*}{\multicolumn{2}{|c|}{$\mathrm{H}^{+}$Conc, $\mathrm{M}$}} & \multirow{2}{*}{$\begin{array}{c}\mathrm{U} \\
\text { Conc, } \\
\mathrm{M}\end{array}$} & \multirow{2}{*}{\multicolumn{2}{|c|}{ Solids }} & \multirow[b]{2}{*}{$\begin{array}{l}\text { Mo/U Mole Ratio } \\
\text { in Solids }\end{array}$} \\
\hline & & & & & & \\
\hline 3 & 5.0 & 0.43 & 1.22 & 38.9 & 28.2 & 1.80 \\
\hline 3 & 8.0 & 1.25 & 1.64 & 40.0 & 31.1 & 1.93 \\
\hline 3 & 11.0 & 5.55 & 1.58 & - & 60.1 & - \\
\hline 10 & 5.0 & 0.80 & 0.94 & 40.0 & 38.5 & 2.39 \\
\hline 10 & 8.0 & 3.20 & 1.05 & 5.05 & 55.6 & 27.3 \\
\hline 10 & 11.0 & 5.50 & 1.11 & 0.21 & 61.5 & 727 \\
\hline 10 & 4.0 & 0.23 & 0.85 & 39.6 & 27.9 & 1.75 \\
\hline 10 & 6.0 & 1.68 & 0.96 & 40.3 & 31.4 & 1.93 \\
\hline 10 & 10.0 & 4.45 & 1.12 & 0.46 & 60.8 & 328 \\
\hline
\end{tabular}

Dissolution in Nitric Acid-Ferric Nitrate Solutions. Ferric and phosphate ions strongly complex molybdenum in dilute nitric acid solution. Heteropolymolybdate ions are formed by reactions similar to the following (15, 16):

$$
\begin{aligned}
2 \mathrm{Fe}^{3+}+12 \mathrm{MOO}_{3}+6 \mathrm{H}_{2} \mathrm{O} & \longrightarrow\left(\mathrm{Fe}_{2} \mathrm{Mo}_{12} \mathrm{O}_{42}\right)^{6-}+12 \mathrm{H}^{+} \\
2 \mathrm{PO}_{4}{ }^{\mathrm{E}}+18 \mathrm{MOO}_{3} & \longrightarrow\left(\mathrm{P}_{2} \mathrm{Mo}_{18} \mathrm{O}_{62}\right)^{6-}
\end{aligned}
$$

At each acid concentration, uranium-molybdenum alloys dissolved in nitric acid-ferric nitrate solutions more rapidly than in nitric acid alone. For example, the initial (5-min) rate of dissolution of U-3\% Mo alloy in boiling $8 \mathrm{M} \mathrm{HNO}_{3}$ increased from 142 to about $200 \mathrm{mg} \mathrm{min}^{-1} \mathrm{~cm}-2$ as the ferric nitrate concentration increased from $O$ to $1 M$ (Table 6). A complete study of the off-gases has not yet been made. However, work at HAPO () indicated that the gas mixture evolved during dissolution was about $70 \%$ No and $25 \% \mathrm{NO}_{2}$. Less than $0.2 \%$ hydrogen was present in the gas.

In most cases, the dissolution rate showed a first-order dependence on the ferric nitrate concentration regardless of the nitric acid concentration. The data were found to fit approximately the 
Table 6. Initial Rates of Dissolution of Uranium-Molybdenum Alloys in Boiling Nitric Acid-Ferric Nitrate Solutions

\begin{tabular}{|c|c|c|c|}
\hline $\begin{array}{c}\text { Mo in Alloy, } \\
\%\end{array}$ & $\begin{array}{l}\mathrm{HiNO}_{3} \\
\text { Conc, } \mathrm{M}\end{array}$ & $\begin{array}{l}\mathrm{Fe}\left(\mathrm{NO}_{3}\right)_{3} \\
\text { Conc, } \mathrm{M}^{3}\end{array}$ & $\begin{array}{l}\text { Rate, } \\
\mathrm{mg} \min ^{-1} \mathrm{~cm}^{-2}\end{array}$ \\
\hline 3 & 3.0 & $\begin{array}{l}0.0 \\
0.25 \\
0.50 \\
0.75 \\
1.0\end{array}$ & $\begin{array}{l}20 \\
30 \\
42 \\
65 \\
93\end{array}$ \\
\hline 3 & 8.0 & $\begin{array}{l}0.0 \\
0.25 \\
0.50 \\
0.75 \\
1.0\end{array}$ & $\begin{array}{l}142 \\
195,177 \\
204,224 \\
201,199 \\
200,197\end{array}$ \\
\hline 3 & 10.0 & $\begin{array}{l}0.0 \\
0.25 \\
0.50 \\
0.75 \\
1.0\end{array}$ & $\begin{array}{l}199 \\
311,279 \\
241 \\
223 \\
205\end{array}$ \\
\hline 8.4 & 5.0 & $\begin{array}{l}0.0 \\
0.25 \\
0.50 \\
0.75 \\
1.0 \\
1.0\end{array}$ & $\begin{array}{r}10 \\
34 \\
60 \\
89 \\
94 \\
103\end{array}$ \\
\hline 10 & 3.0 & $\begin{array}{l}0.0 \\
0.25 \\
0.50 \\
0.75 \\
1.0\end{array}$ & $\begin{array}{l}26 \\
50 \\
57 \\
76 \\
90\end{array}$ \\
\hline 10 & 8.0 & $\begin{array}{l}0.0 \\
0.25 \\
0.50 \\
0.75 \\
1.0\end{array}$ & $\begin{array}{l}77 \\
91,90 \\
114 \\
125 \\
132\end{array}$ \\
\hline 10 & 10.0 & $\begin{array}{l}0.0 \\
0.5 \\
0.75 \\
1.0\end{array}$ & $\begin{array}{r}90 \\
126 \\
146 \\
148\end{array}$ \\
\hline
\end{tabular}


following type of equation:

$$
R\left(m g \min ^{-1} \mathrm{~cm}^{-2}\right)=\mathrm{k}\left(\mathrm{HNO}_{3}, \underline{\mathrm{M}}\right)^{\mathrm{n}}+\mathrm{j}(\mathrm{Fe}, \underline{\mathrm{M}})^{\mathrm{p}}
$$

With an alloy of known composition, the quantity $\mathrm{k}\left(\mathrm{HNO}_{3}\right)^{\mathrm{n}}$ may be expressed as a constant, $\mathrm{K}$, at each nitric acid concentration. The $\mathrm{K}$ may be evaluated from the values of $\mathrm{k}$ and $\mathrm{n}$ in Table 3 and the nitric acid concentration. Equation 2 then becomes

$$
R=K+j(F e)^{p}
$$

or, by rearranging and taking logarithms,

$$
\log (R-K)=\log j+p \log (F e)
$$

The quantity $(R-K)$ is the increase in rate due to the presence of ferric nitrate. Plots of $\log (\mathrm{R}-\mathrm{K})$ vs $\log (\mathrm{Fe})$ were linear with slopes equal to $\mathrm{p}$, the order of the reaction with respect to the ferric nitrate concentration (Fig. 5). Values for $\mathrm{p}$ and $j$ (Table 7 ) show that the reaction for

Table 7. Constants Obtained When Dissolution Rates in Nitric AcidFerric Nitrate Solutions were Correlated by the Equation

$$
\text { Rate }=\mathrm{k}\left(\mathrm{HNO}_{3}\right)^{\mathrm{n}}+\mathrm{j}(\mathrm{Fe})^{\mathrm{p}}
$$

\begin{tabular}{cccc}
\hline Mo in Alloy, & $\mathrm{HNO}_{3}$ Conc, & $\mathrm{p}$ & $\mathrm{j}$ \\
\hline 3 & 3 & 1.14 & 75.9 \\
3 & 3 & 1.42 & 66.7 \\
3 & 8 & 0.22 & 82.8 \\
3 & 8 & 0.32 & 67.0 \\
8.4 & 5 & 0.90 & 91.2 \\
10 & 3 & 0.75 & 61.9 \\
10 & 8 & 1.05 & 64.9 \\
10 & 10 & 1.05 & 64.9 \\
\hline
\end{tabular}




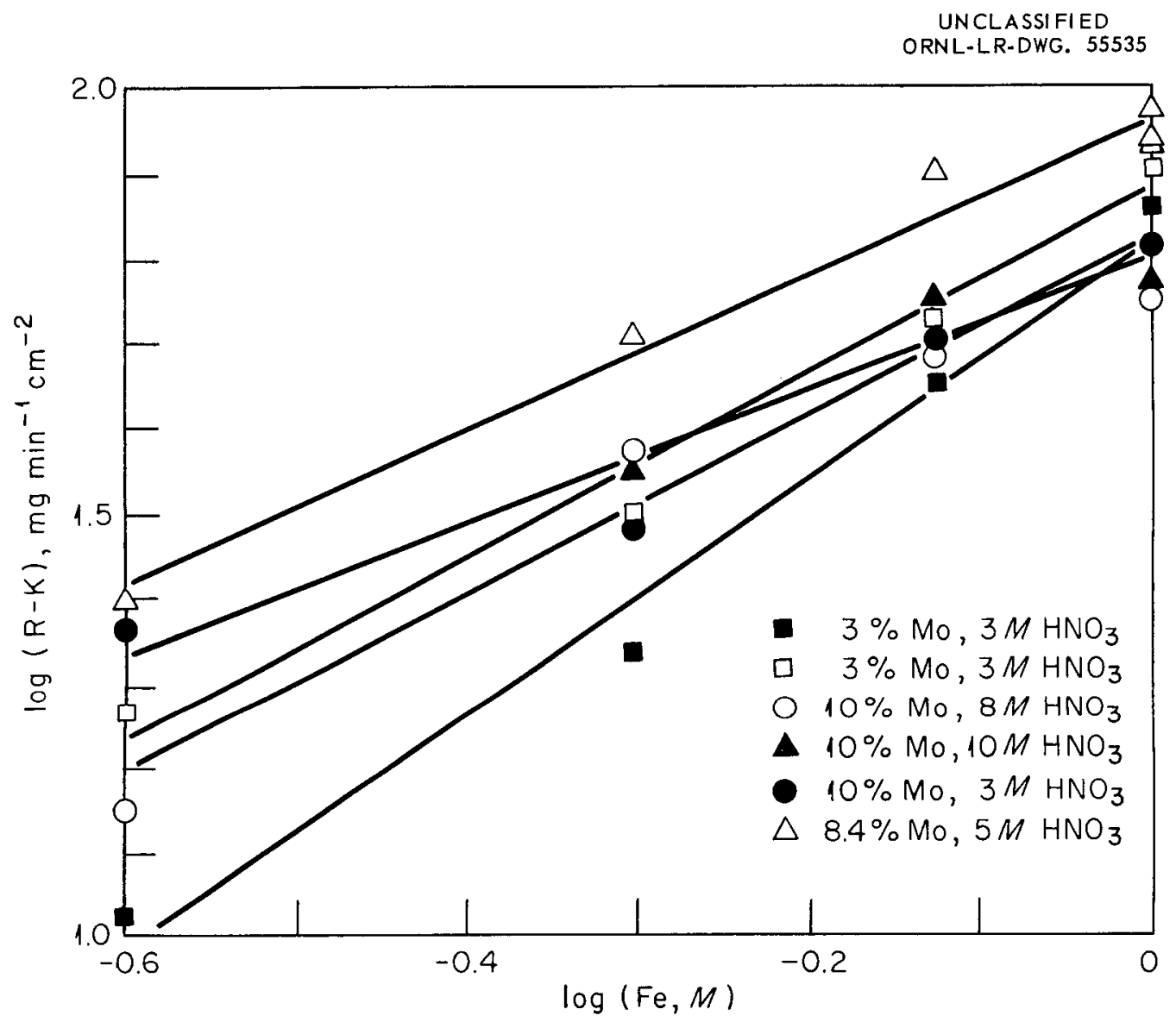

Fig. 5. Correlation of dissolution rates of uranium-molybdenum alloys in boiling nitric acid-ferric nitrate solutions by use of eq. 4 . Slopes of the lines indicate a firstorder dissolution rate with respect to the ferric nitrate concentration.

the rate increase due to ferric nitrate is approximately first order with respect to the ferric nitrate concentration, with the rate constant being about 65 . The fact that the rate data can be correlated by means of an equation of the form of eq. 2 indicates that uranium-molybdenum alloys dissolve by means of separate, competing reactions involving nitric acid and ferric nitrate. 
The presence of ferric nitrate apparently had little effect on the amount of acid consumed, which generally varied between 3 and 5 moles per mole of alloy dissolved (Table 8). For convenience it is assumed that 4 moles of nitric acid is consumed in the dissolution of 1 mole of alloy.

Table 8. Consumption of Nitric Acid in Dissolution of Uranium-Molybdenum Alloys in Boiling Nitric Acid--Ferric Nitrate Solutions

\begin{tabular}{|c|c|c|c|c|c|}
\hline $\begin{array}{l}\overline{\text { Mo in }} \\
\text { Alloy, } \\
\% \\
\end{array}$ & $\begin{array}{l}\text { Initial } \\
\mathrm{HNO}_{3} \\
\text { Conc, } \mathrm{M}\end{array}$ & $\begin{array}{l}\mathrm{Fe}\left(\mathrm{NO}_{3}\right)_{3} \\
\mathrm{Conc}, \mathrm{M}^{3}\end{array}$ & $\begin{array}{c}\text { Alloy } \\
\text { Dissolved, } \\
\text { moles }\end{array}$ & $\begin{array}{c}\text { Acid } \\
\text { Consumed, } \\
\text { moles }\end{array}$ & $\begin{array}{l}\text { Moles Acid Consumed } \\
\text { Mole Alloy Dissolved }\end{array}$ \\
\hline 0 & 5.0 & 1.0 & 0.0286 & 0.207 & 7.2 \\
\hline 0 & 5.0 & 1.0 & 0.0321 & 0.179 & 5.6 \\
\hline 3 & 5.0 & 0.3 & 0.0840 & 0.332 & 4.0 \\
\hline 3 & 5.0 & 0.7 & 0.0846 & 0.354 & 4.2 \\
\hline 3 & 5.0 & 1.0 & 0.0872 & 0.376 & 4.3 \\
\hline 3 & 8.0 & 0.5 & $1.01^{\mathrm{a}}$ & $5.36^{a}$ & 5.3 \\
\hline 3 & 8.0 & 0.5 & 0.0488 & 0.266 & 5.4 \\
\hline 3 & 8.0 & 0.5 & 0.0523 & 0.297 & 5.7 \\
\hline 3 & 8.0 & 0.5 & 0.0414 & 0.174 & 4.2 \\
\hline 8.4 & 5.0 & 0.25 & $0.732^{\mathrm{a}}$ & $2.01^{a}$ & 2.7 \\
\hline 8.4 & 5.0 & 0.50 & $0.661^{a}$ & $1.78^{\mathrm{a}}$ & 2.7 \\
\hline 8.4 & 5.0 & 0.75 & $0.793^{a}$ & $2.50^{\mathrm{a}}$ & 3.2 \\
\hline 8.4 & 5.0 & 1.0 & $0.931^{\mathrm{a}}$ & $3.06^{2}$ & 3.3 \\
\hline 8.4 & 5.0 & 1.0 & $0.814^{a}$ & $2.50^{a}$ & 3.1 \\
\hline 8.4 & 5.0 & 1.0 & $1.061^{\mathrm{a}}$ & $3.54^{\mathrm{a}}$ & 3.3 \\
\hline 8.4 & 5.0 & 1.0 & $0.924^{a}$ & $3.25^{\mathrm{a}}$ & 3.5 \\
\hline 8.4 & 5.0 & 1.0 & 0.0652 & 0.250 & 3.8 \\
\hline 8.4 & 5.0 & 1.0 & 0.0691 & 0.240 & 3.5 \\
\hline 8.4 & 5.0 & 1.0 & 0.0686 & 0.253 & 3.7 \\
\hline 8.4 & 5.0 & 1.0 & 0.0702 & 0.301 & 4.3 \\
\hline 8.4 & 5.0 & 1.0 & 0.0715 & 0.321 & 4.5 \\
\hline 10 & 2.0 & 1.0 & 0.0301 & 0.0650 & 2.2 \\
\hline 10 & 5.0 & 1.0 & 0.0604 & 0.201 & 3.3 \\
\hline 10 & 8.0 & 1.0 & $0.092 a$ & 0.359 & 3.9 \\
\hline
\end{tabular}

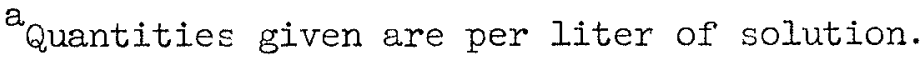


Densities at $26^{\circ} \mathrm{C}$ of nitric acid-ferric nitrate solutions containing less than 0.1 molybdenum are given in Fig. 6 and can be expressed by the equation

$$
\mathrm{d}^{2}(\mathrm{~g} / \mathrm{ml})=0.0719\left(\mathrm{HNO}_{3}, \underline{\mathrm{M}}\right)+0.425(\mathrm{Fe}, \underline{\mathrm{M}})+0.994
$$

The boiling points of several nitric acid-ferric nitrate and nitric acidphosphoric acid solutions are given in Table 9.

Table 9. Boiling Points of Several Nitric Acid-Ferric Nitrate and Nitric Acid-Phosphoric Acid Solutions

\begin{tabular}{cccc}
\hline $\mathrm{HNO}_{3}$ Conc, & $\mathrm{Fe}\left(\mathrm{NO}_{3}\right)_{3}$ Conc, & $\mathrm{H}_{3} \mathrm{PO}_{4}$ Conc, & $\begin{array}{c}\text { Boiling } \\
{ }_{\mathrm{C}}\end{array}$ \\
\hline 3 & 0 & 0 & 101 \\
3 & 0.25 & 0 & 102 \\
3 & 0.5 & 0 & 103 \\
3 & 1.0 & 0 & - \\
8 & 0 & 0 & 108 \\
8 & 0.25 & 0 & 110 \\
8 & 0.5 & 0 & 112 \\
8 & 1.0 & 0 & 114 \\
10 & 0 & 0 & 112 \\
10 & 0.25 & 0 & 113 \\
10 & 0.5 & 0 & 114 \\
10 & 1.0 & 0 & 118 \\
& & & \\
3 & 0 & 0.25 & 101 \\
3 & 0 & 0.5 & 102 \\
3 & 0 & 1.0 & 103 \\
8 & 0 & 0.25 & 108 \\
8 & 0 & 0.5 & 109 \\
8 & 0 & 1.0 & 110 \\
10 & 0 & 0.25 & 111 \\
10 & 0 & 0.5 & 112 \\
10 & 0 & 1.0 & 113 \\
\hline
\end{tabular}

Dissolution in Nitric Acid-Phosphoric Acid Solutions. Uraniummolybdenum alloys dissolve at high rates in nitric acid-phosphoric acid solutions, with maximum rates at about $0.25 \mathrm{M} \mathrm{H}_{3} \mathrm{PO}_{4}$ ( $\mathrm{Fig} .7$ ). For example, the rate of dissolution of uranium-3\% molybdenum alloy in boiling $10 \mathrm{M}_{-} \mathrm{HNO}_{3}$ 


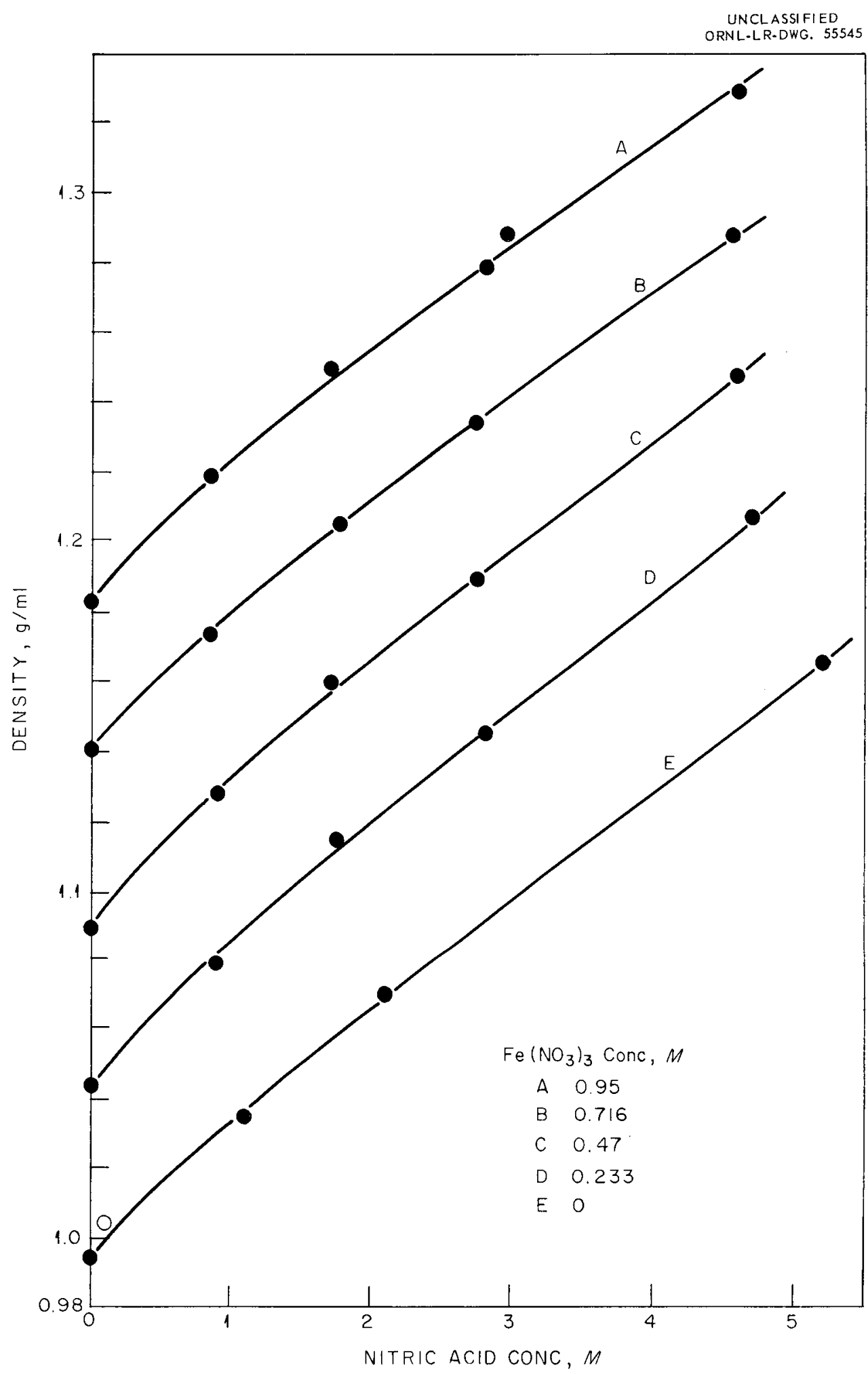

Fig. 6. Densities of nitric acid-ferric nitrate solutions at $26^{\circ} \mathrm{C}$ (molybdenum concentration less than $0.1 \underline{M}$ ). 
UNCL.ASSIFIED

ORNL-LR-DWG. 55546

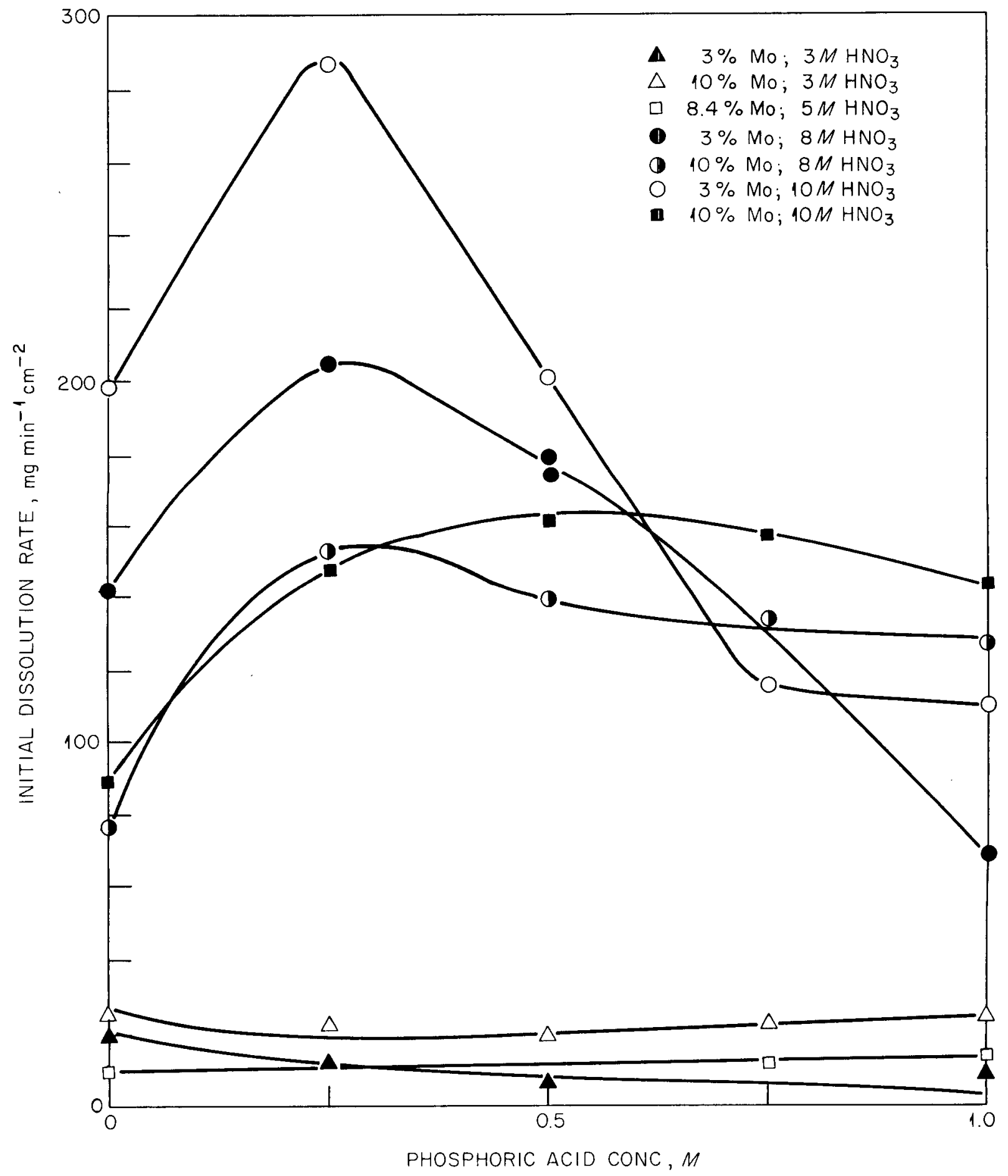

Fig. 7. Effect of nitric acid concentration, phosphoric acid concentration, and alloy composition on the rate of dissolution of uranium-molybdenum alloys in boiling nitric acid-phosphoric acid solutions. 
increases from 200 to about $290 \mathrm{mg} \mathrm{min}^{-1} \mathrm{~cm}^{-2}$ when the phosphoric acid concentration is increased from 0 to $0.25 \mathrm{M}$; a further increase in phosphoric acid concentration to $1 \mathrm{M}$ causes a decrease in rate to about $110 \mathrm{mg} \mathrm{min}-1 \mathrm{~cm}^{-2}$. As expected, in solutions of constant phosphoric acid concentration the rate increased with increasing nitric acid concentration. With alloys containing 3 and $10 \%$ molybdenum, the rate of reaction in boiling 8 to $10 \mathrm{MNNO}_{3}$ containing $\mathrm{O}$ to $I \mathrm{M}$ phosphoric acid was always greater than $60 \mathrm{mg} \mathrm{min}{ }^{-1} \mathrm{~cm}^{-2}$.

In boiling 5 to $12 \mathrm{M} \mathrm{HNO}_{3}$ containing 0 to $1 \mathrm{M} \mathrm{H}_{3} \mathrm{PO}_{4}$, between 3 and 5 moles of hydrogen ion was consumed in the dissolution of 1 mole of 10\% Mo alloy irrespective of the initial acid or phosphate concentration (Table 10). However, the nitrate ion consumption increased from about 1.5 to about 3 moles per mole of alloy dissolved when the acid concentration was increased from 5 to $12 \mathrm{M}$. The phosphate concentration did not change significantly during dissolution.

\subsection{Solubility Data}

The solubilities of $\mathrm{MoO}_{3}, \mathrm{MOO}_{3} \cdot 2 \mathrm{H}_{2} \mathrm{O}$, and $\mathrm{UO}_{2} \mathrm{MOO}_{4}$ were measured in various nitric acid, nitric acid-ferric nitrate, nitric acid-phosphoric acid and sodium hydroxide solutions to aid in the determination of optimum process conditions.

The various molybdenum compounds used in the solubility studies were prepared as follows: $\mathrm{MoO}_{3} \cdot 2 \mathrm{H}_{2} \mathrm{O}$ was freshly precipitated before use by acidifying a solution of c.p. grade sodium molybdate according to the procedure given by Freedman (17). Hydrous $\mathrm{MOO}_{3}$ was obtained by digesting about $120 \mathrm{~g}$ of c.p. sodium molybdate with $8 \underline{\mathrm{M}} \mathrm{HNO}_{3}$ for about $15 \mathrm{hr}$, filtering

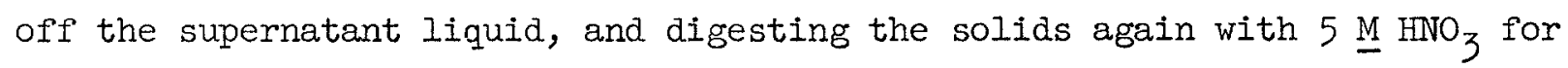
$5 \mathrm{hr}$. The final product was $\mathrm{MOO}_{3}$ containing about $3 \%$ water. $\mathrm{UO}_{2} \mathrm{MoO}_{4}$ was obtained by mixing $25 \mathrm{ml}$ of $1 \mathrm{M} \mathrm{Na}_{2} \mathrm{MoO}_{4}$ solution with $25 \mathrm{ml}$ of $1.08 \mathrm{M} \mathrm{UO}_{2}\left(\mathrm{NO}_{3}\right)_{2}$ solution at room temperature. After water washing, the yellow solid contained $22.2 \%$ molybdenum. $\mathrm{UO}_{2} \mathrm{MoO}_{4}$ contains $22.3 \%$ molybdenum.

All samples were equilibrated at least 3 weeks before analysis. 
Table 10. Consumption of Hydrogen Ion and Nitrate Ion in the Dissolution Uranium-10\% Molybdenum Alloy in Boiling $\mathrm{HNO}_{3}=\mathrm{H}_{3} \mathrm{PO}_{4}$ Solutions

\begin{tabular}{|c|c|c|c|c|}
\hline \multirow{2}{*}{$\begin{array}{c}\text { Initial } \mathrm{HNO}_{3} \\
\text { Conc, } \mathrm{M} \\
\end{array}$} & \multicolumn{2}{|c|}{$\mathrm{H}_{3} \mathrm{PO}_{4}$ Conc, $\underline{\mathrm{M}}$} & \multicolumn{2}{|c|}{$\begin{array}{c}\text { Moles Consumed } \\
\text { per Mole of Alloy }\end{array}$} \\
\hline & Initial & Final & Hydrogen Ion & Nitrate \\
\hline 5.0 & 0 & 0 & 2.9 & 0.6 \\
\hline 5.0 & 0.05 & 0.05 & 3.8 & 1.4 \\
\hline 5.0 & 0.1 & 0.11 & 3.4 & 1.3 \\
\hline 5.0 & 0.25 & 0.26 & 3.4 & 1.5 \\
\hline 5.0 & 0.5 & 0.48 & 2.9 & 1.6 \\
\hline 5.0 & 1.0 & 0.98 & 2.8 & 1.6 \\
\hline 8.0 & 0 & 0 & 3.9 & - \\
\hline 8.0 & 0.05 & 0.05 & 3.3 & 1.8 \\
\hline 8.0 & 0.1 & 0.11 & 3.2 & 1.8 \\
\hline 8.0 & 0.25 & 0.25 & 4.9 & 2.2 \\
\hline 8.0 & 0.5 & 0.51 & 3.6 & 1.8 \\
\hline 8.0 & 1.0 & 1.1 & 3.1 & 1.7 \\
\hline 12.0 & 0.05 & 0.05 & 6.3 & 4.2 \\
\hline 12.0 & 0.1 & 0.11 & 4.8 & 3.0 \\
\hline 12.0 & 0.25 & 0.27 & 4.5 & 3.1 \\
\hline 12.0 & 0.5 & 0.56 & 4.5 & 3.0 \\
\hline 12.0 & 1.0 & - & 4.0 & 2.8 \\
\hline
\end{tabular}

Solubility of Molybdenum Oxide in Nitric Acid. At $26^{\circ} \mathrm{C}$, the solubility of $\mathrm{MOO}_{3} \cdot 2 \mathrm{H}_{2} \mathrm{O}$ attains its maximum value of about $0.13 \mathrm{M}$ when the nitric acid concentration is about $3.5 \mathrm{M}$ (Fig. 8a) (18). The solubility of $\mathrm{MoO}_{3}$ in nitric acid is also maximum at about $3 \underline{M}$ acid, but is only about $0.05 \mathrm{M}$ (Fig. 8a). The solubilities of $\mathrm{MOO}_{3} \cdot 2 \mathrm{H}_{2} \mathrm{O}$ and $\mathrm{MOO}_{3}$ (19) decrease with increasing temperature in solutions where the nitric acid concentration is greater than about 2 M (Fig. 8a). Data obtained by Cannon (20) with $\mathrm{MoO}_{3} \cdot \mathrm{H}_{2} \mathrm{O}$ indicate that the solubility is nil in solutions where the acid concentration is greater than about 6 M. For maximum separation of the molybdenum, then, dissolution of $10 \%$ alloys in nitric acid must be carried out under conditions which ensure that the acidity of the solution produced is greater than $6 \mathrm{M}$.

If the uranium had a negligible effect on the solubility, alloys containing 3 and 10\% molybdenum could be dissolved in nitric acid to produce 
solutions containing about $3 \mathrm{M} \mathrm{HNO}_{3}$ and 0.18 and $0.65 \underline{\mathrm{M}}$ uranium, respectively. Actually, the highest uranium concentration achieved with $3 \%$ alloys was about $0.6 \underline{\mathrm{M}}$.

Solubility of $\mathrm{MOO}_{3} \cdot 2 \mathrm{H}_{2} \mathrm{O}$ in Nitric Acid-Uranyl Nitrate Solutions. In solutions where the nitric acid concentration was less than about $2 \underline{M}$, the solubility of $\mathrm{MOO}_{3} \cdot 2 \mathrm{H}_{2} \mathrm{O}$ was lowered by the presence of uranyl nitrate (Fig. 8b) (18). For example, in about $3.5 \mathrm{M} \mathrm{HNO}_{3}$, the solubility was reduced from 0.13 to $0.07 \mathrm{M}$ when the uranyl nitrate concentration was increased from 0 to $0.95 \mathrm{M}$. Corresponding data for the solubility of $\mathrm{MoO}_{3}$ were not obtained, but it is assumed that uranyl nitrate would have a similar effect, and that the solubility values would be slightly lower than those obtained with the dihydrate. The fact that the solubility of the dihydrate is higher in solutions containing uranium at low acidity is an indication that some complex ion formation occurs between uranium and molybdenum in these solutions.

Solubility of Uranyl Molybdate $\left(\mathrm{UO}_{2} \mathrm{MOO}_{4}\right)$ in Nitric Acid. Since the solids formed in the dissolution of uranium-molybdenum alloys in nitric acid appeared to be a series of uranyl molybdates (Sect. 3.2), it was of interest to determine the solubility behavior of such compounds in nitric acid. When the nitric acid concentration after dissolution was greater than about $4 \underline{M}$, the solids formed were $\mathrm{MOO}_{3}$. The solubility of this compound in nitric acid was discussed above. However, when the dissolution was carried out under such conditions that solids precipitated from solutions with an acid concentration less than $4 \underline{M}$, the solids contained both uranium and molybdenum (Table 5).

The normal molybdate, $\mathrm{UO}_{2} \mathrm{MOO}_{4}$, was selected for study. In solutions containing less than about $3 \underline{\mathrm{M}} \mathrm{HNO}_{3}$, uranium and molybdenum from the solids were solubilized to about the same extent (Fig. 9). However, at higher acidities the molybdenum solubility decreased from its maximum value of about $0.18 \mathrm{M}$; the uranium concentration increased with increasing acid concentration in all cases. These data further illustrate that solids, if formed during dissolution with nitric acid, are best washed either with water or with nitric acid more concentrated than $4 \underline{M}$ if significant solubilization of the molybdenum is to be avoided. 

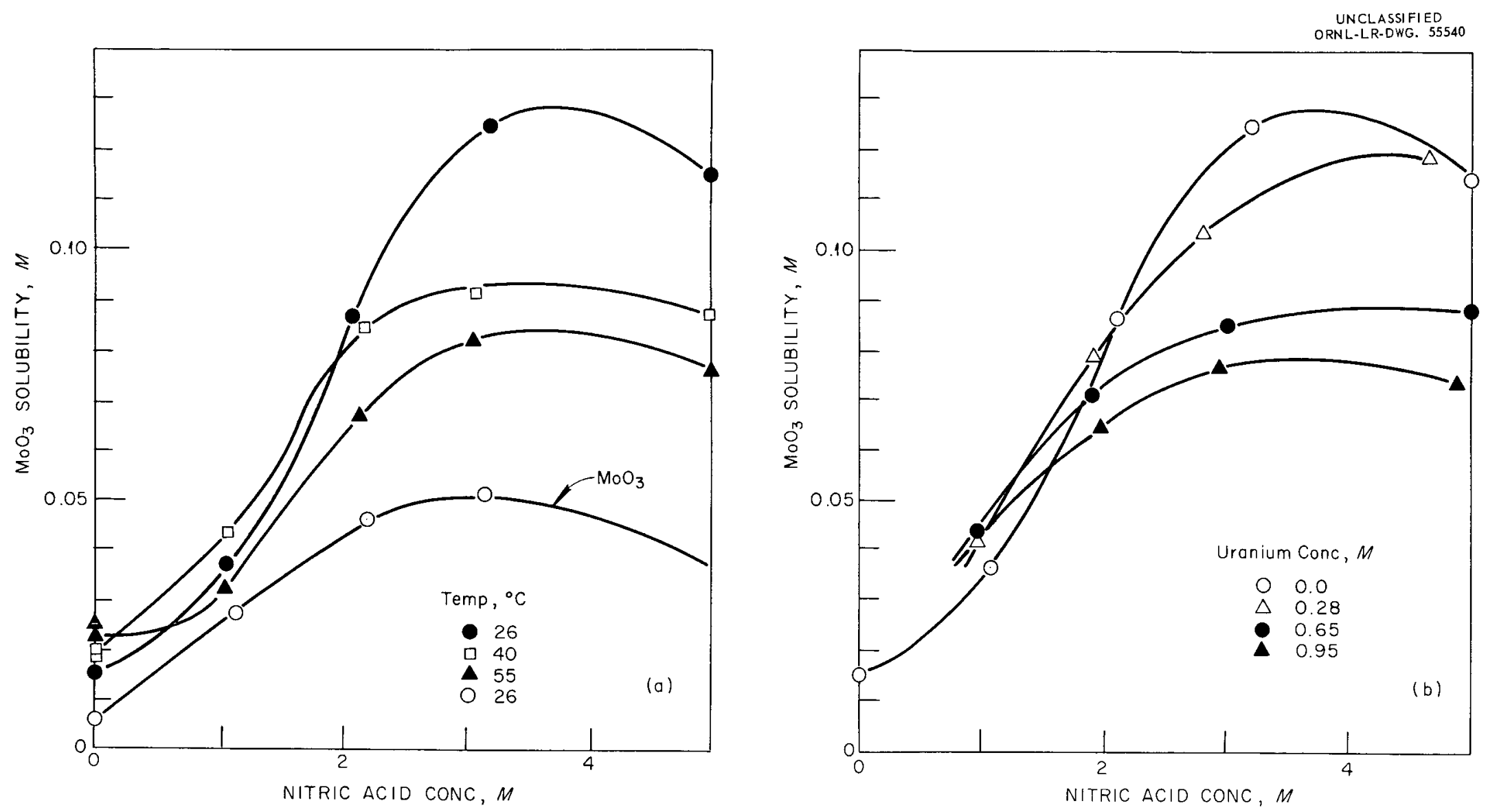

Fig. 8. Solubility (a) of $\mathrm{MoO}_{3} \cdot 2 \mathrm{H}_{2} \mathrm{O}$ in nitric acid at various temperatures and of $\mathrm{MoO}_{3}$ at $26^{\circ} \mathrm{C}$; and (b) of $\mathrm{MoO}_{3} \cdot 2 \mathrm{H}_{2} \mathrm{O}$ in nitric acid-uranyl nitrate solutions at $26^{\circ} \mathrm{C}$. 
The uranium content of the solid phase after equilibration decreased wi.th increasing acid concentration (Table 11), as expected from the results given in Fig. 9. Within the limits of error, the variation in composition of the solid phase with acid concentration was the same as that in solids obtained from dissolution of the alloys (see Fig. 4 ).

Table 11. Solid Phases Resulting from Equilibration of UO, $\mathrm{MOO}_{4}$ with Nitric Acid at $26^{\circ} \mathrm{C}$

\begin{tabular}{|c|c|c|c|}
\hline \multirow[b]{2}{*}{$\begin{array}{l}\text { Nitric Acid. } \\
\text { Conc, M } \\
\end{array}$} & \multicolumn{2}{|c|}{ Composition } & \multirow[b]{2}{*}{$\begin{array}{l}\text { Mo/U Mole Ratio } \\
\text { in Solids }\end{array}$} \\
\hline & $\frac{\text { of So] }}{\text { Uranium }}$ & $\frac{\text { Phase, } \%}{\text { Molybdenum }}$ & \\
\hline 0.73 & 34.5 & 26.9 & 1.94 \\
\hline 1.54 & 36.0 & 29.0 & 2.00 \\
\hline 2.30 & 20.6 & 38.1 & 4.59 \\
\hline 3.56 & 0.36 & 43.8 & 302 \\
\hline
\end{tabular}

Solubility of Molybdenum Oxide in Nitric Acid-Ferric Nitrate Solutions. Stabilities of solutions resulting from the dissolution of uranium-3\% and $-10 \%$ molybdenum alloys in nitric acid-ferric nitrate solutions were reported by HAPO (8). These data, which showed the maximum alloy concentration attainable in dilute nitric acid solutions containing up to 1 M ferric nitrate, are useful in determining conditions for preparing Redox process solvent extraction feed solutions. The solubility studies reported here were undertaken to obtain data in more concentrated acid solutions and in solutions containing no uranium. The latter data are useful in selecting conditions for storing aqueous Purex-type solvent extraction wastes.

The solubilities of both $\mathrm{MOO}_{3}$ and $\mathrm{MOO}_{3} \cdot 2 \mathrm{H}_{2} \mathrm{O}$ were determined in nitric acid-ferric nitrate solutions. The solubilities at $26^{\circ} \mathrm{C}$ were affected by the ferric nitrate and nitric acid concentrations in a similar manner, i.e., the solubility of the dihydrate (18) was about twice that of the oxide (Table 12), other conditions being the same (Figs. 10 and 11). When the 


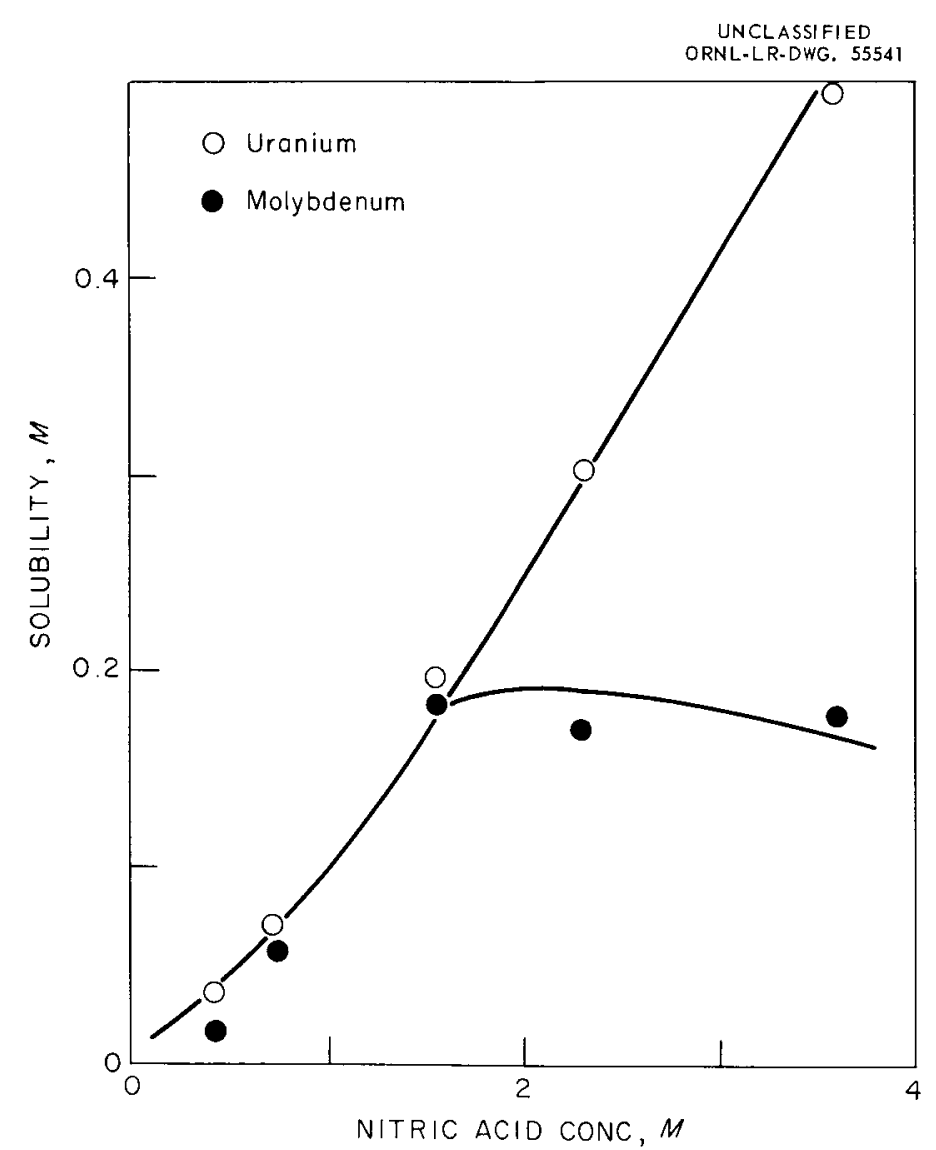

Fig. 9. Solubility of $\mathrm{UO}_{2} \mathrm{MoO}_{4}$ in dilute nitric acid solutions at $26^{\circ} \mathrm{C}$. ${ }^{2} \mathrm{O}_{4}$ indilute

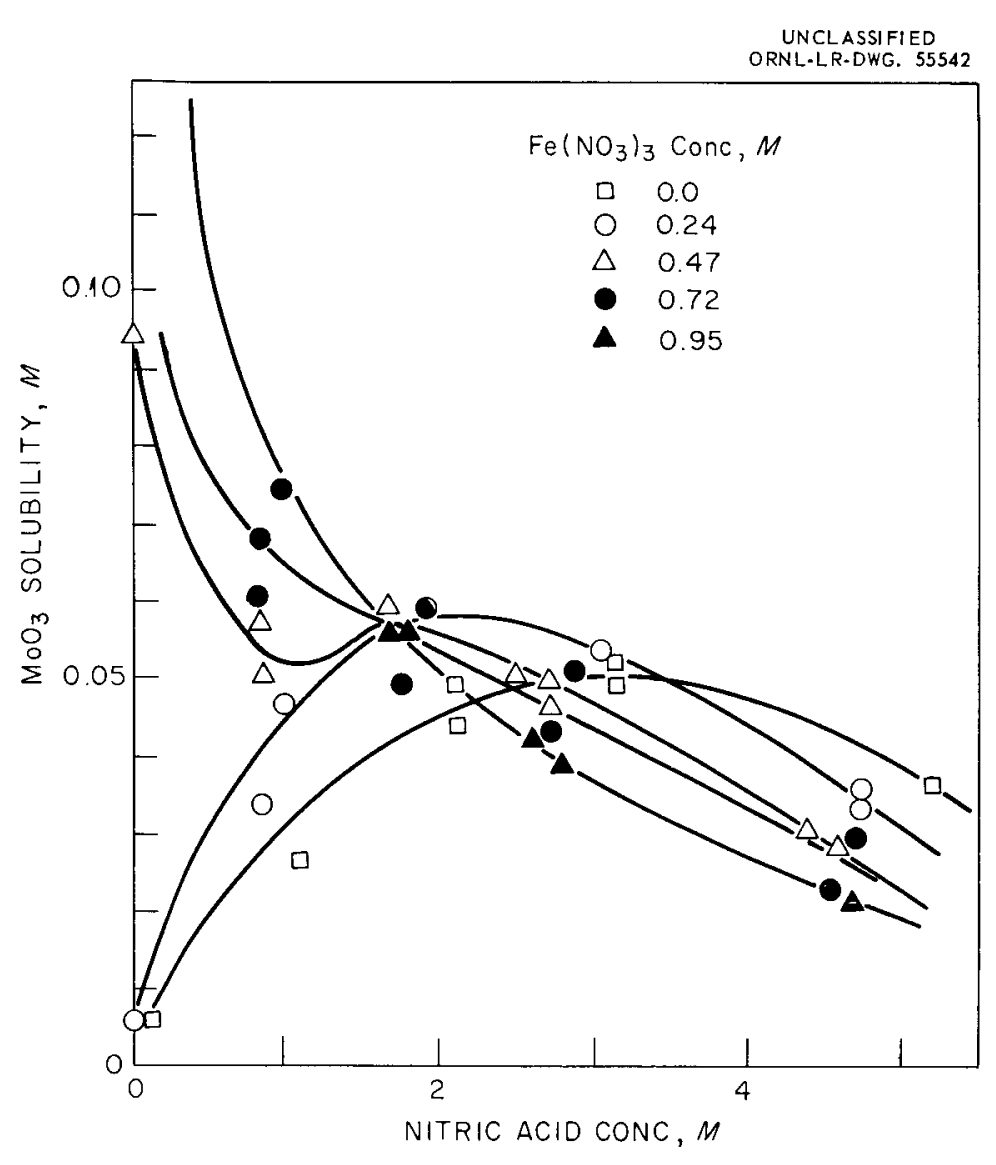

Fig. 10. Solubility of $\mathrm{MoO}_{3}$ in aqueous nitric acid-ferric nitrate solutions at $26^{\circ} \mathrm{C}$. 
Table 12. Solubility of $\mathrm{MoO}_{3}$ in Nitric Acid and Nitric Acid-Ferric Nitrate Solutions at $26^{\circ} \mathrm{C}$

\begin{tabular}{|c|c|c|c|c|c|}
\hline $\begin{array}{c}\text { Fe Conc, } \\
M \\
\end{array}$ & $\begin{array}{l}\mathrm{H}^{+} \text {Ion } \\
\text { Conc, } \mathrm{M}\end{array}$ & $\begin{array}{c}\text { Mo Conc, } \\
M\end{array}$ & $\begin{array}{c}\mathrm{Fe} \text { Conc, } \\
\mathrm{M} \\
\end{array}$ & $\begin{array}{l}\mathrm{H}^{+} \text {Ion } \\
\text { Conc, } \mathrm{M}\end{array}$ & $\begin{array}{c}\text { Mo Conc, } \\
\mathrm{M} \\
\end{array}$ \\
\hline 0 & 0.11 & 0.0066 & 0.716 & 0.84 & $0.0608,0.0677$ \\
\hline 0 & 1.08 & 0.0269 & 0.717 & 0.97 & 0.0743 \\
\hline 0 & 2.12 & $0.0443,0.0490$ & 0.713 & 1.75 & 0.0493 \\
\hline 0 & 3.14 & $0.0493,0.0521$ & 0.752 & 1.93 & 0.0597 \\
\hline \multirow[t]{2}{*}{0} & 5.20 & 0.0364 & 0.713 & 2.73 & 0.0434 \\
\hline & & & 0.752 & 2.88 & 0.0511 \\
\hline 0.233 & 0.0 & 0.0056 & 0.705 & 4.55 & 0.0227 \\
\hline 0.233 & 0.86 & $0.0329,0.0337$ & 0.717 & 4.70 & 0.0295 \\
\hline 0.242 & 1.00 & 0.0468 & & & \\
\hline 0.242 & 1.95 & 0.0598 & 0.950 & 0.0 & 0.262 \\
\hline 0.242 & 3.05 & 0.0534 & 0.951 & 1.67 & $0.0508,0.0554$ \\
\hline 0.231 & 4.73 & $0.0333,0.0332$ & 0.950 & 1.80 & 0.0563 \\
\hline \multirow[t]{2}{*}{0.233} & 4.75 & 0.0359 & 0.950 & 2.60 & 0.0426 \\
\hline & & & 0.951 & 2.78 & 0.0388 \\
\hline 0.476 & 0.0 & 0.0941 & 0.942 & 4.60 & $0.0225,0.0239$ \\
\hline 0.476 & 0.81 & 0.0575 & 0.950 & 4.70 & 0.0217 \\
\hline 0.467 & 0.88 & 0.0505 & & & \\
\hline 0.476 & 1.67 & 0.0595 & & & \\
\hline 0.471 & 1.73 & 0.0551 & & & \\
\hline 0.476 & 2.50 & 0.0501 & & & \\
\hline 0.473 & 2.73 & $0.0461,0.0499$ & & & \\
\hline 0.456 & 4.40 & 0.0301 & & & \\
\hline 0.460 & 4.58 & 0.0283 & & & \\
\hline
\end{tabular}

nitric acid concentration was constant and less than $2 \underline{M}$, the solubilities increased with increasing ferric nitrate concentration. On the other hand, the solubilities were always lowered by the addition of ferric nitrate to solutions having nitric acid concentrations greater than about $3 \underline{M}$.

The solubility data point out the advantage of using iron to complex molybdenum in dilute nitric acid solutions. Experience has shown that the data for the dihydrate best describe the solubility limitations to be expected in the dissolution of alloys. 
Although the effect of uranium on the solubility of molybdenum oxide in nitric acid-ferric nitrate solutions was not investigated directly, data from HAPO (8) showed the solubility in dilute nitric acid of alloys containing 3 and $10 \%$ molybdenum to increase with increasing nitric acid concentration when the ferric nitrate concentration was constant. Solubilities were not determined in solutions more concentrated in nitric acid than 3 to $4 \underline{M}$. Increasing the ferric nitrate concentration increased the solubility in solutions of constant acidity.

Although ferric nitrate is useful in complexing molybdenum during alloy dissolution, its presence in solution complicates subsequent waste handling. For example, dissolution of a fuel containing $3 \%$ molybdenum according to the flowsheet shown in Fig. Ib would result in about 1100 gal of high-activity solvent extraction waste solution for each ton of fuel processed even if the waste should be concentrated to $0.25 \mathrm{M}$ molybdenum. The solubility data show that this molybdenum concentration is attainable only in solutions of very low acidity. Extreme care would be required in the partial neutralization and evaporation of the waste to avoid precipitation of ferric hydroxide.

Solubility of $\mathrm{MOO}_{3}$ in Nitric Acid-Phosphoric Acid Solutions. The solubility of $\mathrm{MoO}_{3}$ was determined at $26^{\circ} \mathrm{C}$ in solutions which were initially 0 to $5 \mathrm{M}$ nitric acid containing 0 to $0.5 \mathrm{M}$ phosphoric acid (Table 13). The solubility was highest in solutions containing no nitric acid and passed through a maximum of about $2.2 \mathrm{M}$ when the phosphoric acid concentration was about $0.3 \mathrm{M}$ (Fig. 12). In solutions of constant phosphoric acid concentration the solubility decreased with increasing nitric acid concentration; e.g., from about 2.2 to $0.12 \mathrm{M}$ in solutions containing $0.3 \underline{\mathrm{M}}$ phosphoric acid when the nitric acid concentration was increased from 0 to $5 \underline{M}$. The solubilities in solutions containing no nitric acid were much higher than those observed by Cannon (20) for the monohydrate, $\mathrm{MoO}_{3} \cdot \mathrm{H}_{2} \mathrm{O}$.

As illustrated by the lower curves in Fig. 12, little benefit is derived from the use of phosphoric acid as a complexing agent for molybdenum in solutions where the nitric acid concentration is greater than about $2 \underline{M}$. This behavior, in addition to the fact that ferric ion is required to complex the phosphate in the subsequent solvent extraction step (21), makes the use of phosphate impractical. 
c

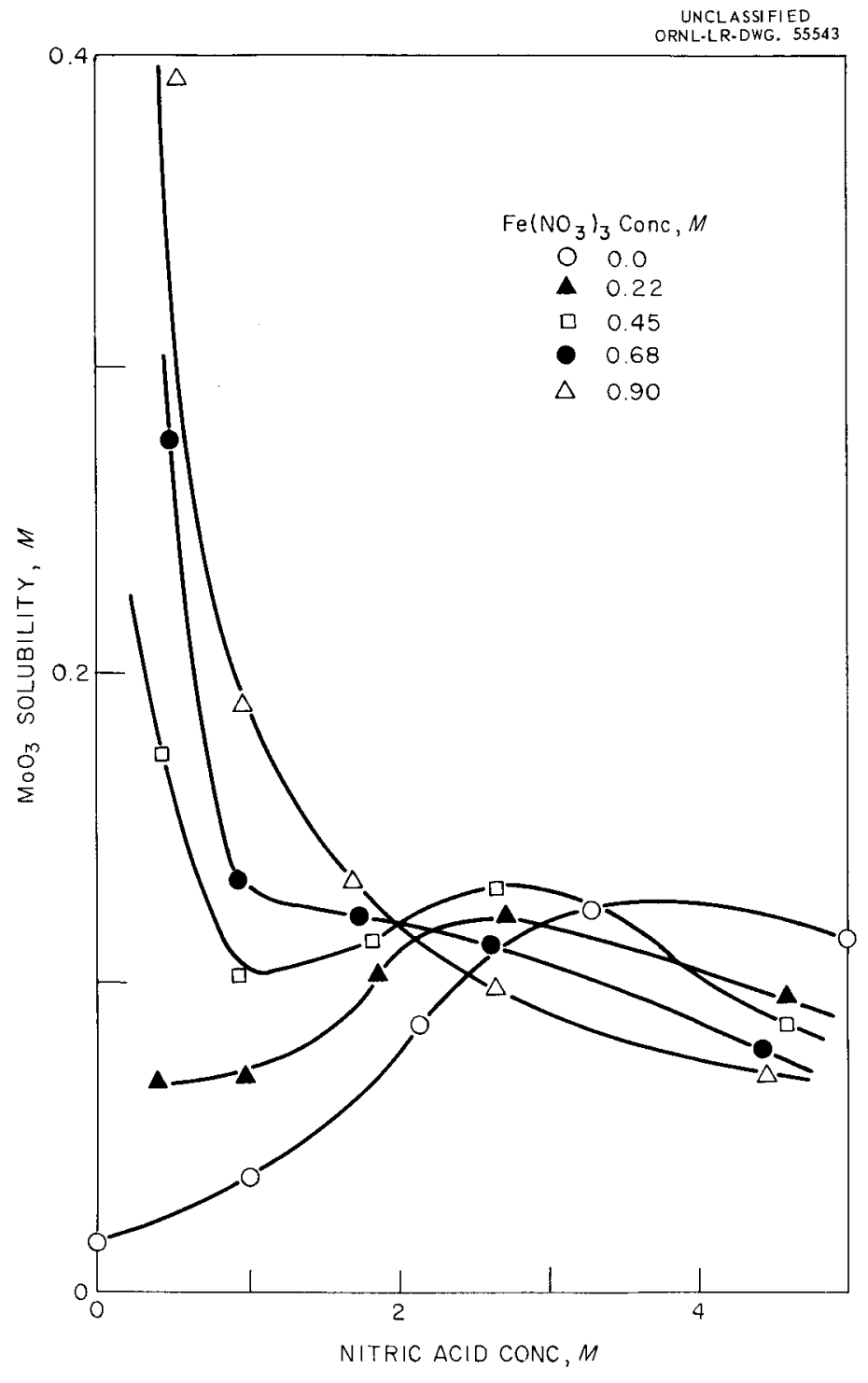

Fig. 11. Solubility of $\mathrm{MoO}_{3} \cdot 2 \mathrm{H}_{2} \mathrm{O}$ in nitric acid-ferric nitrate solutions at $26^{\circ} \mathrm{C}$.

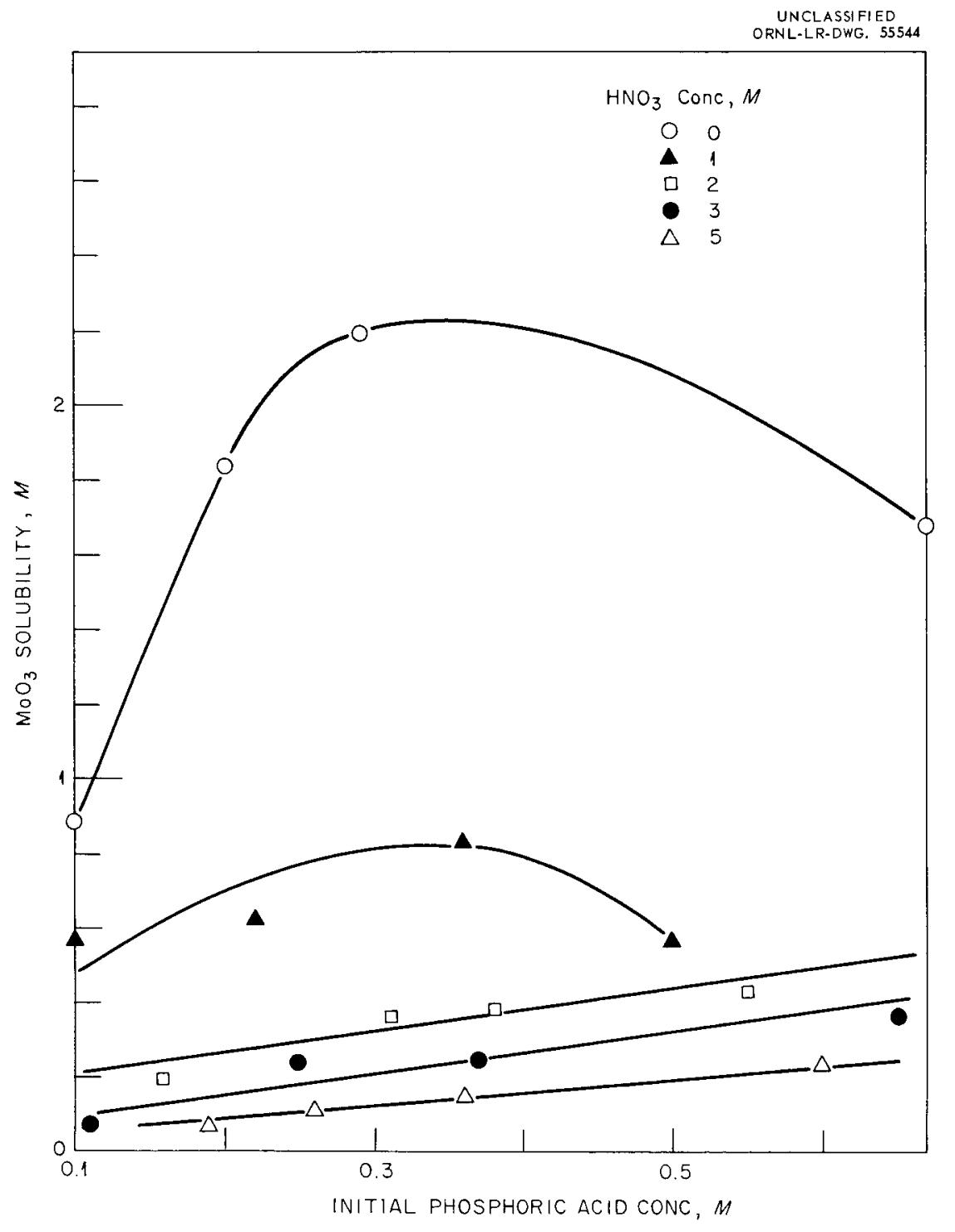

Fig. 12. Solubility of $\mathrm{MoO}_{3}$ in nitric acidphosphoric acid solutions at $26^{\circ} \mathrm{C}$ as a function of initial acid concentrations.

$\stackrel{\dot{w}}{\varphi}$ 
Table 13. Solubility of $\mathrm{MoO}_{3}$ in Nitric Acid-Phosphoric Acid Solutions at $26^{\circ} \mathrm{C}$

\begin{tabular}{cccc}
\hline $\begin{array}{c}\text { Initial } \mathrm{HNO}_{3} \\
\text { Conc, } \mathrm{M}\end{array}$ & $\begin{array}{c}\text { Initial } \mathrm{H}_{3} \mathrm{PO}_{4} \\
\text { Conc, } \mathrm{M}\end{array}$ & $\begin{array}{c}\text { Mo Conc, } \\
\mathrm{M}\end{array}$ & $\begin{array}{c}\text { Density of } \\
\text { Saturated Solution, } \\
\mathrm{g} / \mathrm{ml}\end{array}$ \\
\hline 0 & 0.1 & 0.893 & 1.1064 \\
0 & 0.2 & 1.84 & 1.2293 \\
0 & 0.29 & 2.20 & 1.2575 \\
0 & 0.67 & 1.69 & 1.2318 \\
1 & 0.1 & 0.577 & 1.1156 \\
1 & 0.22 & 0.629 & 1.1391 \\
1 & 0.36 & 0.837 & 1.1448 \\
1 & 0.5 & 0.566 & 1.1656 \\
2.16 & 0.16 & 0.204 & 1.0892 \\
2.24 & 0.31 & 0.367 & 1.1170 \\
2.40 & 0.38 & 0.391 & 1.1259 \\
2.60 & 0.55 & 0.439 & 1.1394 \\
3.20 & 0.11 & 0.079 & 1.1162 \\
3.22 & 0.25 & 0.243 & 1.1235 \\
3.33 & 0.37 & 0.254 & 1.1396 \\
3.40 & 0.65 & 0.369 & 1.1632 \\
5.04 & 0.19 & 0.076 & 1.1726 \\
5.10 & 0.26 & 0.115 & 1.1808 \\
5.10 & 0.36 & 0.148 & 1.1888 \\
5.12 & 0.60 & 0.240 & 1.2079 \\
\hline
\end{tabular}

Solubility of $\mathrm{MOO}_{3}$ in Sodium Hydroxide Solutions. The solubility of sodium molybdate in sodium hydroxide solutions was measured to aid in determining the optimum conditions for storage of the basic waste solutions. At $26^{\circ} \mathrm{C}$ the solubility decreased from about 2.8 to $1.25 \mathrm{M}$ as the sodium hydroxide concentration increased from 0 to about $4.5 \mathrm{M}$ (Table 14). The solubility in water was estimated from data given by Seidell (22). The other solubility data are in excellent agreement with those reported by Bye (23).

3.4 Corrosion Studies

Titanium-45A, 304L stainless steel, Hastelloy $\mathrm{F}$ and Ni-o-nel appear suitable as materials of construction for processes involving nitric acid

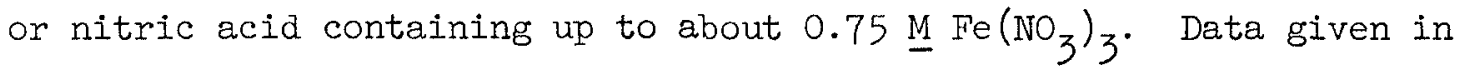


Table 14. Solubility of Sodium Molybdate in Sodium Hydroxide Solutions at $26^{\circ} \mathrm{C}$

\begin{tabular}{lcc}
\hline $\begin{array}{l}\mathrm{NaOH} \text { Conc, } \\
\mathrm{Ma}\end{array}$ & $\mathrm{Na}_{2} \mathrm{MoO}_{4} \begin{array}{c}\text { Solubility, } \\
\mathrm{M}\end{array}$ & $\begin{array}{c}\text { Density of Solution, } \\
\mathrm{g} / \mathrm{ml}\end{array}$ \\
\hline $0 \quad(\mathrm{ref} .22)$ & $\sim 2.8$ (ref. 22) & $\sim 1.47$ (ref. 22) \\
0.38 & 2.55 & 1.4395 \\
0.76 & 2.44 & 1.4302 \\
1.60 & 2.14 & 1.4151 \\
2.72 & 1.86 & 1.3951 \\
4.44 & 1.26 & 1.3635 \\
\hline
\end{tabular}

Table 15 show that the rate of corrosion of titanium-45A was less than $0.1 \mathrm{mil} /$ month in boiling 3 to $8 \mathrm{M} \mathrm{HNO}_{3}$ containing $0.5 \mathrm{M} \mathrm{Fe}\left(\mathrm{NO}_{3}\right)_{3}$, $0.6 \mathrm{MUO}_{2}\left(\mathrm{NO}_{3}\right)_{2}$, and $0.02 \mathrm{M} \mathrm{MOO}_{3}(24,25)$. After $1000 \mathrm{hr}$ in test, the general attack was negligible and there was no evidence of extensive localized attack. Work at HAPO (26) showed that corrosion of $304 \mathrm{~L}$ stainless steel, Ni-o-nel, and vacuum-melted Hastelloy $F$ was severe in solutions containing $1 \mathrm{M} \mathrm{Fe}\left(\mathrm{NO}_{3}\right)_{3}$ but that rates were acceptably low when the ferric nitrate concentration was less than about $0.6 \mathrm{M}$.

Table 15. Corrosion of Titanium-45A in Boiling Nitric Acid Solutions Containing $0.5 \mathrm{M} \mathrm{Fe}\left(\mathrm{NO}_{3}\right)_{3}, 0.6 \mathrm{M} \mathrm{UO}_{2}\left(\mathrm{NO}_{3}\right)_{2}$, and $0.02 \mathrm{M} \mathrm{MOO}_{3}$

Duration of tests $=1000 \mathrm{hr}$

\begin{tabular}{cccc}
\hline $\mathrm{HNO}_{3}$ Conc, & \multicolumn{3}{c}{ Corrosion Rate, mils/month } \\
\cline { 2 - 4 } & Vapor & Interface & Solution \\
\hline 3.0 & 0.01 & 0.01 & 0.01 \\
5.0 & 0.02 & 0.01 & Gain \\
8.0 & 0.05 & Gain & 0.01
\end{tabular}

Data from ref. 25 . 


\subsection{MISCELLANEOUS RELATED STUDIES}

4.1 Dissolution in Dilute Aqua Regia

Uranium-8.4\% molybdenum alloy was readily dissolved in boiling $5 \mathrm{M} \mathrm{HNO}_{3}-$ $2 \mathrm{M} \mathrm{HCl}$ to produce a solution which was stable only below 0.14 M uranium, showing that chloride was relatively ineffective as a complexing agent for molybdenum. Since the chloride must also be removed prior to solvent extraction,this method offers no advantages over direct dissolution in nitric acid.

4.2 Other Potential Complexing Agents for Molybdenum Scouting experiments showed that Co(II), Cr(III), Ni(II), AI(III), $\mathrm{Mg}$ (II), and $\mathrm{As}(\mathrm{V})$ in $5 \mathrm{M} \mathrm{HNO}_{3}$ were less efficient than $\mathrm{Fe}(\mathrm{III})$ for complexing molybdenum.

4.3 Reduction of Solvent Extraction Waste Volumes

Since solvent extraction waste volumes are expected to be high when ferric ion is used to complex molybdenum, scouting studies were performed to find means for producing concentrated waste solutions. One potential method involves neutralization of the iron-bearing waste solution with sodium hydroxide, allowing the ferric hydroxide to precipitate. If the supernatant solution is adjusted to about $1 \mathrm{M} \mathrm{NaOH}$, the iron is essentially quantitatively precipitated with solubilization of 81 to $86 \%$ of the molybdenum. The molybdenum removal would probably have been higher if more refined experimental methods had been used. After the separation, the sodium molybdate solution can be concentrated by evaporation to about $2 \mathrm{M}$ molybdenum (Table 14) and the ferric hydroxide dissolved in dilute nitric acid for storage or recycle as dissolvent.

In methods involving the use of nitric acid only, the solvent extraction raffinate will probably be about $3 \mathrm{MHNO}_{3}$ containing up to $0.05 \mathrm{M}$ molybdenum. These solutions, when boiled down to produce solutions boiling at about $121^{\circ} \mathrm{C}$, result in the precipitation of most of the molybdenum and concentration of the nitric acid to 13 to $15 \mathrm{M}$. The residue from such a boildown is readily dissolved in dilute sodium hydroxide. Measurement of the temperature (which allows estimation of the nitric acid concentration) and the volume of the solution will define the amount of sodium hydroxide required to neutralize 
the excess acid and dissolve the molybdic oxide. The caustic solutions would be concentrated before being admitted to waste tanks.

\subsection{Decladding of Zirconium-clad Fuels}

Fuels like the Detroit Edison core (3) are composed of uranium-molybdenum alloy clad in zirconium or Zircaloy-2. The possibility of removing the cladding with boiling ammonium fluoride or $\mathrm{NH}_{4} \mathrm{~F}-\mathrm{NH}_{4} \mathrm{NO}_{3}$ solutions (Zirflex process (27)) was cursorily investigated. In boiling $6 \underline{\mathrm{M}} \mathrm{NH}_{4} \mathrm{~F}$ or $6 \mathrm{MNH}_{4} \mathrm{~F}-1 \mathrm{M} \mathrm{NH}_{4} \mathrm{NO}_{3}$ the rate of attack on alloys containing either 3 or 10\% molybdenum was too great for a decladding procedure to be considered:

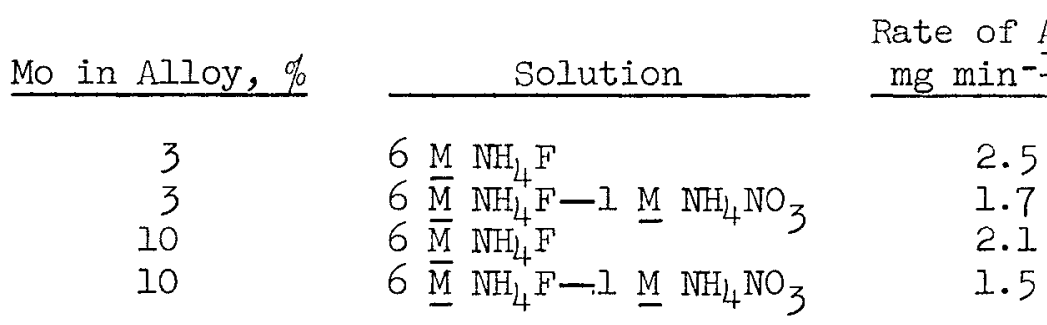

There is a possibility, however, that hydrofluoric acid could be used to declad U-10\% Mo alloy fuels. Initial rates of dissolution of this alloy in 5-9 $\mathrm{M} \mathrm{HF}$ were generally less than $0.2 \mathrm{mg} \mathrm{min-1} \mathrm{cm}^{-2}$ (28).

\subsection{REFERENCES}

1. E. R. Irish and W. H. Reas, "The Purex Process: A Solvent Extraction Reprocessing Method for Irradiated Uranium," in "Symposium on the Reprocessing of Irradiated Fuels, Brussels, Belgium, May 20-25, 1957," TID $-7534, \mathrm{p} .83$.

2. J.W. Ullmann, "Reactor Data Sheet, Consumers Public Power," Aug. 22, 1960, personal compilation.

3. J. W. Ullmann, "Reactor Data Sheet, PRDC," June 29, 1959, personal compilation.

4. "Proceedings of the AEC Symposium for Chemical Processing of Irradiated Fuels from Power, Test, and Research Reactors, Richland, Washington, October 20-21, 1959," TID-7583. 
a) C. D. Watson, J. B. Adams, G. K. Ellis, G. A. West, F. L. Hannon, W. F. Schaffer, and B. B. Klima, "Mechanical Processing of spent Reactor Fuel at Oak Ridge National Laboratory," p. 307.

b) R. E. Blanco, L. M. Ferris, J. R. Flanary, F. G. Kitts, R. H. Rainey, and J. T. Roberts, "Chemical Processing of Power and Research Reactor Fuels at Oak Ridge National Laboratory," p. 234.

5. R. E. Blanco, "Processing of Power Reactor Fuels," Nucl. Sci. Eng., 1:409 (1956).

6. V. B. Shevchenko, N. S. Povitsky, and A. S. Salovkin, "Treatment of Irradiated Fuel Elements," P/2182, Proc. 2nd UN Internatl. Conf. on Peaceful Uses of Atomic Energy, Geneva, 1958, Vol. 17, p. 46, UN, New York.

7. W. W. Schulz, "Reprocessing Uranium-Molybdenum Alloy Fuels: Dissolution in Concentrated Nitric Acid," HW-64432 (March 17, 1960).

8. W. W. Schulz and E. M. Duke, "Reprocessing of Low-Enrichment UraniumMolybdenum Alloy Fuels," HW-62086 (Sept. 15, 1959).

9. E. S. Occhipinti, "Reprocessing of Power Reactor Fuels, Third Quarterly Progress Report, April 1 - July 1, 1958," DP-318 (December, 1958).

10. T. A. Gens, "An Oxyhydrochlorination Process for Preparing UraniumMolybdenum Reactor Fuels for Solvent Extraction," ORNL-3019 (in press).

11. R. E. Blanco, "Dissolution and Feed Adjustment," in "Symposium on the Reprocessing of Irradiated Fuels, Brussels, Belgium, May 20-25, 1957," TID-7534, p. 22.

12. K. S. Warren, "Survey of Potential Vapor-phase Explosions in Darex and Sulfex Processes," ORNL-2937 (Dec. 27, 1960).

13. L. H. Meyer, "Reprocessing of Power Reactor Fuels, Quarterly Progress Report, Oct. 1, 1959-Jan. 1, 1960," DP-479 (March, 1960).

14. D. H. Killeffer and A. Linz, "Molybdenum Compounds," Interscience, New York, I952, p. 78 .

15. A. F. Wells, "Structural Inorganic Chemistry," $2 \mathrm{~d}$ ed, Oxford University Press, New York, 1950, p. 348.

16. H. J. Emeléus and J. S. Anderson, "Modern Aspects of Inorganic Chemistry," 2d ed, Van Nostrand, New York, 1952, p. 206. 
17. M. L. Freedman, J. Am. Chem. Soc., 81: 3834 (1959).

18. L. M. Ferris, "The Solubility of Molybdic Oxide in Nitric Acid, Nitric Acid-Uranyl Nitrate, and Nitric Acid-Ferric Nitrate Solutions," ORNL-CF-60-2-94 (Rev. 1), paper submitted for publication.

19. P. Faugeras, Centre D'Etudes Nucléaires de Fontenay-Aux-Roses, France, personal communication, sept. 22, 1960.

20. P. Cannon, J. Inorg. Nucl. Chem., 11: 124 (1959).

21. "Chemical Technology Division Annual Progress Report for Period Ending August 31, 1960," ORNL-2993, p. 50.

22. A. Seidell, "Solubilities of Inorganic and Metal Organic Compounds," 3rd ed, Van Nostrand, New York, 1940, p. 1272.

23. J. Bye, Bull. soc. chim., 10(5): 239 (1943).

24. Letter to F. L. Culler from W. E. Clark, ORNL, "PRFR Corrosion Status Summary and Proposed Program for Remainder of FY-1961," ORNL-CF-60-8-122 (Sept. 8, 1960).

25. Letter to W. E. Clark, ORNL, from L. Rice and D. N. Hess, ORNL, "Corrosion Program in Support of Power Reactor Fuel Reprocessing Program," Sept. 30, 1960.

26. R. F. Maness, "Power Reactor Fuels Reprocessing: Progress Report on Corrosion Aspects," HW-61662 (September 1959).

27. L. M. Ferris, "Zirflex Process for PWR Blanket Fuel. II. Revised Flowsheet," ORNL-2940 (Oct. 26, 1960).

28. W. E. Clark and A. H. Kibbey, "Hydrofluoric Acid Decladding of ZirconiumClad Power Reactor Fuel Elements," ORNL-2460 (Oct. 15, 1958).

\section{NOTEBOOK REFERENCES}

1. J. F. Land, Unclassified Notebooks, A-2020, A-1765, and A-2148.

2. L. M. Ferris, Unclassified Notebook, A-1460. 
-

• 


\author{
ORNL-3068 \\ UC-10 - Chemical Separations \\ Processes for Plutonium and Uranium \\ TID-4500 (16th ed.)
}

\title{
INTERNAL DISTRIBUTION
}

1. Biology Library

2-3. Central Research Library

4. Reactor Division Library

5. ORNL - Y-12 Technical Library, Document Reference Section

6-25. Laboratory Records Department

26. Laboratory Records, ORNL R.C.

27. E. D. Arnold

28. R. E. B1anco

29. G. E. Boyd

30. J. C. Bresee

31. K. B. Brown

32. F. R. Bruce

33. C. E. Center

34-35. F. L. Culler

36. W. K. Eister

37. D. E. Ferguson

38. L. M. Ferris

39. J. R. Flanary

40. J. H. Frye, Jr.

41. J. H. Gillette

42. H. E. Goeller

43. A. T. Gresky

44. W. R. Grimes

45. C. E. Guthrie

46. C. W. Hancher

47. C. S. Harrill

48. A. Hollaender

49. A. S. Householder

50. R. G. Jordan $(Y-12)$

51. W. H. Jordan
52. M. T. Kelley
53. J. F. Land
54. J. A. Lane
55. T. A. Lincoln
56. S. C. Lind
57. R. S. Livingston
58. J. T. Long
59. K. Z. Morgan
60. J. P. Murray (K-25)
61. M. L. Nelson
62. R. H. Rainey
63. H. E. Seagren
64. M. J. Skinner
65. J. A. Swartout
66. E. H. Taylor
67. J. W. Ullmann
68. W. E. Unger
69. C. D. Watson
70. A. M. Weinberg
71. M. E. Whatley
72. C. E. Winters
73. R. G. Wymer
74. J. W. Youngblood
75. D. L. Katz (consultant)
76. C. E. Larson (consultant)
77. I. Perlman (consultant)
78. J. H. Rushton (consultant)
79. H. Worthington (consultant)
80. T. H. Pigford (consultant)

EXTERNAL DISTRIBUTION

81. Division of Research and Development, AEC, ORO

82-594. Given distribution as shown in TID-4500 (16th ed.) under Chemical

Separations Processes for Plutonium and Uranium ( 75 copies - OTS)

595. W. W. Schulz, Hanford Atomic Products Operation 